\title{
Türk Dili ve Edebiyatı Ders Kitaplarındaki Metinlerin Okunabilirlik Düzeyleri
}

\author{
Ömer KEMIKSİZ \\ Bartın Üniversitesi \\ okemiksiz@bartin.edu.tr \\ ORCID: 0000-0001-8628-6203
}

\begin{tabular}{lcc} 
Araştırma Makalesi & DOI: & 10.31592/aeusbed.907768 \\
\hline Geliş Tarihi: 01.04.2021 & Revize Tarihi: 19.10 .2021 & Kabul Tarihi: 11.11 .2021
\end{tabular}

\section{Atıf Bilgisi}

Kemiksiz, Ö. (2021). Türk Dili ve Edebiyatı ders kitaplarındaki metinlerin okunabilirlik düzeyleri. Ahi Evran Üniversitesi Sosyal Bilimler Enstitüsü Dergisi, 7(3), 973-992.

\section{ÖZ}

$\mathrm{Bu}$ araştırmanın amacı ortaöğretim Türk Dili ve Edebiyatı ders kitaplarındaki metinlerin okunabilirlik düzeylerini tespit etmektir. Tarama modelinde doküman incelemesi ile gerçekleştirilen araştırmanın örneklemini Millî Eğitim Bakanlığı Yayınları tarafından 9, 10, 11 ve 12. sınıf düzeyleri için hazırlanan kitaplardaki 40'1 öyküleyici, 36'sı bilgilendirici türde olmak üzere toplam 76 metin oluşturmuştur. Şiir ve tiyatro türündeki metinlerin dâhil edilmediği araştırmada örneklemde yer alan metinlerin okunabilirlik düzeyleri Ateşman (1997) ve Çetinkaya-Uzun (2010) okunabilirlik formüllerine göre incelenmiştir. Ulaş1lan bulgulara göre Ateşman formülünden hareketle incelenen öyküleyici metinlerde 9. sınıfta "kolay" ve "orta güçlükte" metinler eşit sayıdayken 10. sınıfta "orta güçlükte", 11 ve 12. sinıfta "kolay" metinlerin ağırlıkta olduğu; bilgilendirici metinlerde ise bütün sınıf seviyelerinde "orta güçlükte" metinlere daha fazla yer verildiği belirlenmiştir. Çetinkaya-Uzun formülüne göre bütün sınıf düzeylerinde hem öyküleyici hem de bilgilendirici metinlerde "eğitsel" düzeyin öne çıtığı tespit edilmiştir. Metinlerin ortalama kelime ve cümle uzunluklarına bakıldığında bilgilendirici metinlerin öyküleyici metinlere göre daha uzun kelime ve cümlelere sahip olduğu ortaya çıkmıştır. Ateşman formülüne göre örneklemdeki öyküleyici metinlerin \%55'i "kolay", bilgilendirici metinlerin \%56's1 "orta güçlükte" düzeydeyken Çetinkaya-Uzun formülüne göre öyküleyici metinlerin \%83'ünün, bilgilendirici metinlerin ise \%66'sının "eğitsel” düzeyde olduğu görülmüştür.

Anahtar Kelimeler: Türk dili ve edebiyatı, ders kitabı incelemesi, metin, okunabilirlik, okunabilirlik düzeyi.

\section{Readability Levels of Texts in Turkish Language and Literature Textbooks}

\begin{abstract}
The aim of this study is to determine the readability levels of the texts in high school Turkish Language and Literature textbooks. The sample of the study, which was carried out as a document analysis in the survey model, was composed of a total of 76 texts, 40 of which were narrative and 36 were informative, taken from the books prepared by the Ministry of National Education Publications for the 9th, 10th, 11th and 12th-grade levels. The readability levels of the texts in the sample were examined according to the readability formulas of Ateşman (1997) and Çetinkaya-Uzun (2010) in the study, which did not include poetry and theatre texts. According to the findings, in the narrative texts analysed based on the Ateşman formula, there were equal numbers of "easy" and "medium difficulty" texts in the 9th grade, whereas "medium difficulty" texts in the 10th grade, and "easy" level texts in the 11th and 12th grade were the majority. It was also determined that the informative texts included more "medium difficulty" texts at all grade levels. According to the ÇetinkayaUzun formula, it was determined that the "educational" level stands out in both narrative and informative texts at all grade levels. When the average word and sentence lengths of the texts were examined, it was found that the informative texts had longer words and sentences than the narrative texts. According to the Ateşman formula, $55 \%$ of the narrative texts in the sample were "easy," and $56 \%$ of the informative texts were "medium difficulty" level. Additionally, according to the Çetinkaya-Uzun formula, $83 \%$ of the narrative texts and $66 \%$ of the informative texts were at the "educational" level.
\end{abstract}

Keywords: Turkish language and literature, textbook review, text, readability, readability level.

\section{Giriş}

Okuduğunu anlayan ve okumayı alışkanlık hâline getiren bireylerin yetiştirilmesi, bir toplum için en önemli hedeflerdendir. Bu hedefin gerçekleştirilebilmesi için kişilerin daha küçük yaşlardan itibaren nitelikli metin ve kitaplarla tanıştırılmasına çaba ve özen gösterilmesi gerekir. Bunun tersi uygulamalar, kişilerin okumaktan uzaklaşmasına, okumayı zor ve zaman kaybına yol açan bir eylem olarak görmelerine sebep olabilir. Bu nedenle okuma denildiğinde akla ilk gelecek materyallerin başında metinler olduğundan, bu metinlerin seçimi ve nitelikleri göz ardı edilmemesi gereken hususlardandir. 
Dil öğretiminin temel materyalleri kabul edilen (Zorbaz ve Köroğlu, 2016) metinler, Pilav ve Ünalan $(2012$, s. 70) tarafından "belli bir anlam ve biçim bütünlüğü içerisinde duygu ve düşünce açısından bir amaç için oluşturulan dil parçası", Akbayır (2006, s. 215) tarafindan da "belli bir bildirişim bağlamında bir veya daha çok kişi tarafından sözün ya da yazının kullanılmasıyla üretilen bir dil dizgesi bütünü” şeklinde tanımlamaktadır. Dille ilgili kuralların ve sözcüklerin doğal ortamı olan bağlam içerisinde görülerek öğretilmesi metinlerden istifade edilerek gerçekleştirilebilir. Metinlerin bilgi, duygu ve düşüncelerin yerleştirildiği yapılar olduğuna vurgu yapan Güneş (2014), bu yapılarda bilgilerin tesadüfen yer almadığını belirtmektedir. Ayrıca bu bilgilerin yerleştirme işlemi art arda sıralama biçiminde değil, mantıklı bir düzenlemeyle gerçekleştirilir. Başka bir deyişle metinde sözcük, cümle ve paragraflar gelişigüzel değil, belli bir sıra ve düzen içinde, dil bilgisi kurallarına uygun şekilde yerleştirilir. Kelime ve cümlelerin metin vasıtasıyla bir araya gelerek anlamlı bir bütün oluşturduğuna dikkat çeken Kayabaşı, Yılmaz ve Doyumağaç'a (2016) göre de bu bütünlük rastgele bir biçimde değil, kelime ve cümlelerin belirli bir düzen, belli bir sistem ve yapı içerisinde bulunmasıyla alakalıdır. Bundan dolayı bir metin, sadece kelime, cümle ve paragraflara kâğıt üzerinde yer vererek değil, bu unsurların belli bir kompozisyon içerisinde ve birbirleriyle uyumlu şekilde bir araya getirilmesiyle oluşmaktadır denilebilir.

Metinler belirli bir amaç ile yazılmaktadır. Ders kitaplarında kullanılan metinler, çocukların hayal dünyalarını geliştirmek ve onlara dünyaya ait bilgileri kazandırmak amacıyla kaleme alınmaktadır. Metinle karşılaşan hedef kitle o metni okurken zihninde onunla alakalı sorular oluşmalı, okuduklarının sonrası hakkında tahmin yürütmeye çalışmalı, metinde kendi yaşamıyla ilgili bazı şeyleri bulmalı, özdeşleştirmelidir. Ayrıca metindeki anlamı bilinmeyen sözcük sayısı metni okuyan kitleye göre belirlenmelidir ve metinler yazılış amacıyla ilgili olarak kendi içinde ipuçları barındırmalıdır (Akkurt, 2011). Özçetin ve Karakuş'a (2020) göre ders kitaplarında bulunan metinler, ders kitaplarına bir bütünün parçası olarak yerleştirilmiş veya bir eserden alınmış olsa dahi kendi içinde bir bütündür ve bunu okuyana da hissettirmelidir. Metinler ders kitaplarına seçilirken metnin, metin oluşturma kriterlerine uygunluğu, dilin zenginliğinin ve estetik yönünün metne yansitılıp yansıtılmadığı, bilişsel, duyuşsal, sosyolojik açılardan hitap ettiği öğrencilerin düzeyine uygun olup olmadığı gibi farklı değişkenler ön plana çıkarılır. Metinler vasıtası ile sağlıklı bir dil öğretimi gerçekleştirmek için metinlerin öğrencinin düzeyine uygun olması gerektiğini vurgulayan Bağcı'ya (2020) göre öğrenci düzeyinin çok altında kalan metin öğrencide ilgi uyandırmazken çok üstünde olan metin de öğrenciyi zorlayarak onun motivasyonunu azaltabilmektedir. Bu nedenle metin seçimi öğrencinin düzeyi temel alınarak yapılmalıdır. Öğrencilerin okuduğunu anlama seviyelerine ve dil gelişimlerine uygun metinler hazırlamak, öğrencilerin okudukları metinleri hedeflendiği gibi anlamalarını mümkün kılacaktır. Bir metnin okunduğunda anlaşılması ise o metnin okunabilirliğini göstermektedir. Bu sebeple okunabilirlik, okuma eyleminde önemli bir yere sahiptir (Bağc1 ve Ünal, 2013) ve metinlerin okunabilirlik düzeylerini belirlemek, metinlerin ders kitaplarına seçilirken hedef kitleye uygunluğunu anlamanın yollarından biri olarak karşımıza çıkmaktadır (Biçer ve Alan, 2017).

Okunabilirlik, "metinlerin okur tarafindan ne kadar kolay ya da zor anlaşılır olduğu" (Ateşman, 1997, s. 71), "öğrencinin okuduğunu anlama düzeyi ve okuduğu materyali okuma hızı" (Erdem, 2011, s. 22), metnin dil özelliklerini dikkate alarak metinlerin okuyucuya göre anlaş1labilir olması (Yılmaz ve Temiz, 2014) şeklinde tanımlanmaktadır. Okunabilirlikte temel hedef, metinlerin sözcük ve cümle uzunluklarından yola çıarak metnin güçlügünün tespit edilmesi ve bu orandan hareketle metinlerin okurun seviyesine uygun olup olmadığının belirlenmesidir (Baki, 2019). Okunabilirliğin genellikle metinlerin nicel özellikleri yani cümle ve sözcük uzunlukları ve bilinmeyen kelime miktarını dikkate alarak metnin güçlügünü belirlemeyi amaçladığını belirten Zorbaz'a (2007) göre de metinlerin güçlük derecesinin ortaya çıkarılması ve bu doğrultuda metinlerin seviyeye uygunluğunun tespit edilmesi okunabilirliğin ana problemidir. Bu noktada okuma metinlerindeki söz varlığının kullanım sıklığı, yaygınlığı, kelime ve cümle uzunlukları okunabilirliği etkileyen faktörler olarak ifade edilebilir (Karatay, Bolat ve Güngör, 2013). Baş ve İnan-Yıldız'a (2015) göre de okunabilirlik kavramı, okuma materyalindeki sözcüklerin önceki yaşantılarla bağlantılı ve hatırlanabiliyor olmasına, çocuğun içinde bulunduğu sosyal, ekonomik, kültürel düzeye bağlı olarak sahip olduğu söz varlığı unsurlarına, ilgili sınıf ve yaş seviyesine, psikolojik, bilişsel ve duyuşsal 
gelişimine, metinle daha önce karşılaşılıp karşılaşılmamış olmasına göre değişkenlik gösterebileceği gibi metinlerarasılık kavramıyla da ilişkilendirilebilir.

"Okunabilirlik, metinlerin biçimsel özellikleri ile ilişkili bir kavramdır. Metinlerde bir kelimedeki hece sayısı ile bir cümledeki kelime sayısının artması metnin okunabilirlik düzeyini düşürmektedir" (Özbek ve Ergül, 2018, s. 654). Bu sebeple gerek ana dil gerekse yabancı dil öğretiminde okunabilirlik son derece önemlidir. Zira bir metindeki cümleler ve kelimeler hatta heceler uzunsa ve bu durum anlam oluşturmayı zorlaştırıyorsa okunmaları için kendilerine verilen metinler, çocuklar ve yetişkinler tarafindan kabul görmemektedir (Erdem, 2011). Metinlerin okunabilirlik düzeylerinin düşük olması aynı zamanda bu metinleri okuyan kişilerin bilgiler arasında ilişki kurmasını ve metinden anlam çıkarmasını da zorlaştırmaktadır (Özbek ve Ergül, 2018). Bunun yanında kendisine zor gelen bir metinden dolayı, okuduğunu anlama düzeyi zayıf olan bir okuyucunun okumaya karşı cesareti kırılır. Okuduğunu anlama düzeyi daha iyi olan bir okur ise kendisine basit gelen bir metni okurken sıkılır ve okuma isteği azalır (Karatay, Bolat ve Güngör, 2013). Çiftçi, Çeçen ve Melanlığlu'na (2007) göre diğer özellikler içerisinde okunabilirliğin ayrı bir öneme sahip olmas1 bir metnin okunabilirlik düzeyi düşük olduğunda diğer işlevlerini de yerine getirememesinden kaynaklanmaktadır. $\mathrm{Bu}$ nedenle metin seçiminde öncelikli olarak okunabilirlik ele alınmalıdır (Tosunoğlu ve Özlük, 2011). Zira okunabilirlik yönü dikkate alınmadan öğrenciye sunulacak bir metin, sırf bu eksiklik sebebiyle bile istenen/belirlenen kazanımlara erişilmesinde engel teşkil edecektir. $\mathrm{Bu}$ durum ayrıca, çocuğun hayatta başarılı olması için öğrenmesi gereken en temel becerilerden biri olan (Kapıkıran ve Susar-Kırmızı, 2019) ve onların zihinsel ve toplumsal gelişimlerine çok yönlü katkıda bulunan (Duran ve Erkek, 2018) okumayı da olumsuz etkileyecektir.

Bir metnin okur tarafindan kolay algılanmasının metni anlamaya dönük sürecin ilk basamağ 1 şeklinde düşünülebileceğini ifade eden Ateşman'a (1997) göre bununla beraber metinle ilgili nicel verilerin metnin anlaşılabilir olmasını garantileyeceği de söylenemez. Bundan dolayı okunabilirlik ile anlaşılabilirliğin çoğu zaman farklı kavramlar olarak görüldüğü söylenebilir. Çünkü anlaşılabilirlikte, metne ait niceliksel özelliklerin yanında birtakım niteliksel özellikler de söz konusudur. Okunabilirlik ile anlaşılabilirliğin aynı şey olmadığını ifade eden Bozlak'a (2018) göre anlaşılabilirlik metnin niteliği ve içeriği ile ilgilidir. Şayet bu iki özellik birlikte gerçekleşmişse verimli ve etkili bir okuma faaliyetinin gerçekleştiği düşünülebilir. Metindeki cümlelerin öğrencinin düzeyine uygun uzunlukta olması, yine tahmini olarak seviyeye uygun şekilde bilinmeyen veya yabancı sözcüklerin kullanılması, öğrencinin söz varlığını destekler mahiyette bağlamlara yer verilmesi metnin okunabilirliğine ve anlamlandırılabilirliğine katkı sunacaktır. Bir metnin okunabilir ve anlaşılabilirliğini etkileyen birtakım unsurların varlığına işaret eden Mutlu (2020), okuma ortamı, öğrencinin okuma motivasyonu ve okuma becerisi gibi dış faktörlerin yanında metnin kendisinden kaynaklı sebeplerin anlaşılabilirlik üzerinde etkili olduğuna dikkat çekmektedir. Okunabilirliği etkileyen faktörlerden bahseden Çetinkaya (2010) ise bunları çocuğun becerisi ve okuma arzusu, söz dizimi, söz varlığı, kelime uzunluğu, cümle uzunluğu, metnin konu önemi, düzenleniş biçimi, okuma amac1, satır aralığı, baskı biçimi, sütun genişliği ve fizikî ortam şeklinde sıralasa da okunabilirlik çalışmalarında temel unsur metnin kendisiyle ilgili özelliklerdir. Bu bakımdan metnin okunabilirliği söz dizimi, cümle ve kelime uzunluğu, söz varlığı gibi özelliklerle ölçülmektedir. Metinlerin okunabilirliklerini ölçmeye çalışan bazı formüllerin metinlerin nicel özellikleriyle alakadar oldularını ifade eden Çeçen ve Aydemir'e (2011) göre bu da okunabilirliğin anlaşllabilirlikle ilgisi olmadığ izlenimini vermektedir. Ancak nicel özellikler, metindeki dilsel ifadelerin kavranmasında etkili olduğundan dolaylı bile olsa anlamaya etki etmektedir. Metinlerle ilgili birtakım nicel veriler sunan okunabilirlik formüllerinin uygulanması neticesinde ulaşılan veriler, metnin anlaşılması veya anlaşılmamasıyla ilgili kesin sonuçlar vermez. Diğer bir deyişle sadece bu verileri kullanarak metnin kişiye veya bir sınıf seviyesine uygunluğu, zor ya da kolay olduğu sonucuna varılamaz. Ancak okunabilirlik formülleri kullanılarak metin hakkında birtakım sayısal fikirler edinmek mümkün olduğu gibi (Temur, 2003) bu formüller aracılığıyla öğrencilere seviyelerine uygun metinler seçilerek onların öğrenme düzeyleri en üst seviyeye çıkarılabilir (Bağcı ve Ünal, 2013). Bu sebeple metinlerin okunabilirlik düzeylerinin tespit edilmesinde çeşitli formüllerin geliştirilmesinin/ kullanılmasının önemi yadsınamaz. 
Metinlerin okunabilirlik düzeylerinin tanımlanması ve sinıflandırılmasına yönelik alanyazında uzman görüşü ve çıartmalı okunabilirlik işlemiyle birlikte genel kabul görmüş üç yaklaşımdan biri olan, metnin gözlenebilen dil özelliklerinden hareket ederek metinleri okuma güçlüklerine veya kolaylıklarına göre kademeli olarak tasnif etmeyi hedefleyen kestirim araçları (Çetinkaya, 2010) şeklinde ifade edilen okunabilirlik formülleri ile ilgili çalışmalar Türkiye'de 1990'lı yıllarda başlamıştır. O dönemde Türkçe metinler için kullanılabilecek okunabilirlik formülleri henüz oluşturulmadığından Türkçe metinlerin okunabilirlik düzeylerini ölçen ilk çalışmalarda, İngilizce metinler için tasarlanmış formüller kullanılmıştır. Ancak bir dilin yapısının başka bir dile benzememesinden dolayı Türkçe metinler için bu formüllerin uygun olmadığı görülmüştür (Bağcı ve Ünal, 2013; Şakiroğlu, 2020). Bu tarihten sonra Türkçe metinlerin okunabilirliklerinin belirlenmesi için alanyazında geliştirilmiş başlıca üç formül bulunmaktadır. Bunlardan ilki, İngilizce metinlerin okunabilirlik düzeyi için Flesch'in geliştirmiş olduğu formülün Ateşman tarafından 1997 senesinde Türkçeye uyarlanmasıdır. İkincisi Çetinkaya ve Uzun'un 2010 senesinde ortalama sözcük ve cümle uzunluğu verilerinden hareketle Türkçe için geliştirdikleri formüldür. Sonuncusu ise yine aynı sene Bezirci ve Yılmaz tarafindan eserlerdeki toplam cümle sayısı, sözcük sayısı, hece sayısı, çok heceli sözcük sayısının (en az üç heceli) hesaplanmasıyla geliştirilen formüldür (Özçetin ve Karakuş, 2020).

Türkçe metinler için geliştirilen okunabilirlik formüllerinden hareketle araştırmacılar tarafından çeşitli çalışmalar ortaya konmuştur. Konuyla ilgili yapılan araştırmalar incelendiğinde başta ilkokul (Baş ve İnan-Yıldız, 2015; Demir ve Çeçen, 2013; Özbek ve Ergül, 2018; Tosunoğlu ve Özlük, 2011), ortaokul (Bağc1 ve Ünal, 2013; Baki, 2019; Bora, 2019; İskender, 2013; Lüle-Mert, 2018; Okur ve Arı, 2013; Özçetin ve Karakuş, 2020; Özdemir, 2016; Şakiroğlu, 2020) ve yabancılar için Türkçe (Bağc1, 2020; Biçer ve Alan, 2017; Mutlu, 2020; Yılmaz ve Temiz, 2014; Zorbaz ve Köroğlu, 2016) ders kitaplarındaki metinlerin okunabilirlikleri olmak üzere çok sayıda araştırmanın olduğu görülmektedir. Bunun yanında çeşitli edebiyat eserlerinin okunabilirlik düzeylerini belirlemeyi amaçlayan çalışmalar da (Çeçen ve Aydemir, 2011; Çinpolat, 2019; Kayabaş1, Yılmaz ve Doyumağaç, 2016; Özcan, 2020; Özgü-Koçağan, 2012; Teke, 2016; Temizyürek, 2010; Ziya, 2019) mevcuttur. Ancak bununla beraber metne dayalı bir şekilde yürütülen ortaöğretim Türk Dili ve Edebiyatı dersleri için hazırlanan ders kitaplarındaki metinlere dönük araştırmaların eksikliği de dikkat çekmektedir. Literatür taraması neticesinde konuyla ilgili tek çalışmanın Erdem (2011) tarafından yapılan ve Dil ve Anlatım ders kitaplarındaki metinlerin incelendiği araştırma olduğu belirlenmiştir. Bu sebeple Türk Dili ve Edebiyatı ders kitaplarında yer alan metinlerin okunabilirliklerinin tespit edilmesine yönelik araştırmaların artırılmasının bir ihtiyaç olduğu görülmektedir. $\mathrm{Bu}$ araştırma var olan durumdan hareketle Türk Dili ve Edebiyatı ders kitaplarındaki metinlerin okunabilirlik düzeylerini tespit etmeyi ve alanyazına katkı sunmayı amaçlamaktadır. "Türk Dili ve Edebiyatı ders kitaplarındaki metinlerin okunabilirlik düzeyleri nasıldır?” şeklindeki problem cümlesinden hareketle araştırmanın alt problemleri aşağıdaki şekilde oluşturulmuştur:

1. Türk Dili ve Edebiyatı 9. Sınıf Ders Kitabı'ndaki metinlerin okunabilirlikleri hangi düzeydedir?

2. Türk Dili ve Edebiyatı 10. Sınıf Ders Kitabı'ndaki metinlerin okunabilirlikleri hangi düzeydedir?

3. Türk Dili ve Edebiyatı 11. Sınıf Ders Kitabı'ndaki metinlerin okunabilirlikleri hangi düzeydedir?

4. Türk Dili ve Edebiyatı 12. Sınıf Ders Kitabı'ndaki metinlerin okunabilirlikleri hangi düzeydedir?

5. Türk Dili ve Edebiyatı ders kitaplarındaki metinlerin ortalama kelime ve cümle uzunlukları ile okunabilirlik puanlarının sınıf seviyesine ve metin türüne göre dağılımı nasıldır?

6. Okunabilirlik düzeylerinin metin türlerine göre dağılımı nasıldır?

\section{Yöntem}

$\mathrm{Bu}$ bölümde çalışmanın yöntemine yer verilmiştir. Bu başlık altında araştırmanın modeline, veri setine, veri toplama aracına, verilerin toplanması ve analizi aşamalarına değinilmiştir. 


\section{Araștırma Modeli}

Türk Dili ve Edebiyatı ders kitaplarındaki metinlerin okunabilirlik düzeylerini tespit etmeyi amaçlayan bu çalışma tarama modelinde gerçekleştirilmiştir. Geçmişte ya da hâlen var olan bir durumun var olduğu şekliyle betimlenmesini amaçlayan bu modelde araştırmaya konu olan olay, birey ya da nesne, kendi koşulları içinde ve olduğu gibi tanımlanmaya çalışıldığından onları herhangi bir şekilde değiştirme ve etkileme çabası içine girilmez (Karasar, 2005). Araştırmada genel tarama türlerinden biri olan ve değişkenlerin, tek tek, tür ya da miktar olarak oluşumlarının belirlenmesi amacıyla yapılan araştırma modeli (Karasar, 2005) şeklinde ifade edilen tekil tarama modeli kullanılmıştır.

Araştırmanın veri toplama süreci doküman incelemesi ile yürütülmüştür. "Araştırılması amaçlanan olgu veya olgular hakkında bilgi içeren yazılı materyallerin analizini kapsayan" (Yıldırım ve Şimşek, 2011, s. 187) doküman incelemesi, belli bir amaca dönük olarak ilgili kaynakları temin etme, bunları okuma, gerekli notları alma ve elde edilen verileri değerlendirme işlemlerini kapsar (Karasar, 2005). Yıldırım ve Şimşek’e (2011) göre dokümanlar, nitel araştırmalarda etkili şekilde kullanılması gereken bilgi kaynaklarıdır. Araştırmacı, bu tür araştırmalarda ihtiyacı olan veriye, gözlem veya görüşme yapmaya gerek kalmadan ulaşabilir. Doküman incelemesi, gözlem ve görüşme gibi veri toplama teknikleriyle birlikte kullanıldığında verinin çeşitlendirilmesine hizmet ederek araştırma geçerliğini artıran bir öneme de sahiptir. Bu çalışmanın veri toplama sürecinin alt problemler de dikkate alındığında doküman incelemesine uygun olduğu düşünülmektedir.

\section{Veri Seti}

Araştırmanın veri setini ortaöğretim için Millî Eğitim Bakanlığı (MEB) Yayınları tarafından hazırlanmış olan ders kitapları oluşturmaktadır. Bu kitaplar çalışmada aynı yayınevi tarafından bütün sınıf seviyeleri için hazırlanmış olan kitapların incelenmesi amaçlandığından tercih edilmiştir. Veri setini oluşturan kitaplara yönelik bilgilere Tablo 1'de yer verilmiştir.

Tablo 1

Veri Setindeki Kitaplara Yönelik Bilgiler

\begin{tabular}{|c|c|c|}
\hline $\begin{array}{c}\text { Sinıf } \\
\text { Düzeyi }\end{array}$ & $\begin{array}{c}\text { Baskı } \\
\text { Sayısı/Yllı }\end{array}$ & Kabul Bilgileri \\
\hline 9. Sinif & 2-2019 & $\begin{array}{l}\text { Millî Eğitim Bakanlığı, Talim ve Terbiye Kurulunun 28.05.2018 gün ve } 78 \\
\text { sayılı kararı ile ders kitabı olarak kabul edilmiştir. }\end{array}$ \\
\hline 10. Sinif & $2-2019$ & $\begin{array}{l}\text { Millî Eğitim Bakanlığı, Talim ve Terbiye Kurulunun } 28.05 .2018 \text { gün ve } 78 \\
\text { sayılı kararı ile ders kitabı olarak kabul edilmiştir. }\end{array}$ \\
\hline 11. Sinif & $2-2019$ & $\begin{array}{l}\text { Millî Eğitim Bakanlığı, Talim ve Terbiye Kurulunun } 28.05 .2018 \text { gün ve } 78 \\
\text { sayılı kararı ile ders kitabı olarak kabul edilmiştir. }\end{array}$ \\
\hline 12. Sinıf & $2-2019$ & $\begin{array}{l}\text { Millî Eğitim Bakanlığı, Talim ve Terbiye Kurulunun } 28.05 .2018 \text { gün ve } 78 \\
\text { sayılı kararı ile ders kitabı olarak kabul edilmiştir. }\end{array}$ \\
\hline
\end{tabular}

Araştırma kapsamında sınıf düzeylerine göre incelemeye alınan öyküleyici ve bilgilendirici metin sayılarına yönelik bilgiler ise Tablo 2'de yer almaktadır.

Tablo 2

Veri Setindeki Metin Sayılarına Yönelik Bilgiler

\begin{tabular}{cccc}
\hline Sınıf Düzeyi & Öyküleyici Metin (f) & Bilgilendirici Metin (f) & Toplam (f) \\
\hline 9. Sinıf & 6 & 10 & 16 \\
10. Sinıf & 14 & 5 & 19 \\
11. Sinıf & 10 & 13 & 23 \\
12. Sinıf & 10 & 8 & 18 \\
\hline Toplam & 40 & 36 & 76 \\
\hline
\end{tabular}


Tablo 2'de görüldüğü gibi araştırmanın veri setini 9. sınıf kitabında 16; 10. sınıf kitabında 19; 11. sinıf kitabında 23 ve 12. sinıf kitabında 18 olmak üzere 76 metin oluşturmuştur. Bu metinlerin 40’1 (\%53) öyküleyici 36’s1 (\%47) ise bilgilendirici türdedir.

\section{Veri Toplama Aracı}

Araştırma verilerinin elde edilmesinde Ateşman (1997) ve Çetinkaya-Uzun (2010) okunabilirlik formülleri kullanılmıştır. Ateşman (1997) formülü İngilizce metinlerin okunabilirlik düzeyi için Flesch'in geliştirmiş olduğu formülün Türkçeye uyarlanmış hâlidir. $\mathrm{Bu}$ formülün geliştirilmesinde değişik zorluk ve düzeylerde ve farklı alanlardan (bilimsel, felsefi, yazın yapıtları, öğrenci kompozisyonları, haber metinleri) metinler seçilerek bunlar en zor okunanından en kolay okunanına doğru sınıflandırılmıștır. Her metnin bulunan ortalama sözcük ve cümle uzunlukları kullanılmak suretiyle Flesch'in "Reading Ease" diye adlandırılan formülündeki (206.805-0.846x11.015x2) katsayılar Türkçe için hesaplanmaya çalışılmıştır. Formülün hesaplanmasında kullanılan Türkçe en zor metinlerin sözcük uzunluğu üç hece, cümle uzunluğu 30 sözcük; en kolay metinlerin sözcük uzunluğu 2.2 hece, cümle uzunluğu dört sözcük şeklindedir. Yapılan bu hesaplama neticesinde Türkçe metinlerin okunabilirliğinin tespit edilebilmesi için 198.825-40.175xA-2.610xB (A: Ortalama kelime uzunluğu B: Ortalama cümle uzunluğu) formülü geliştirilmiştir.

Çetinkaya-Uzun (2010) formülü ise Çetinkaya ve Uzun tarafindan Türkçe metinler için geliştirilmiş bir formüldür. Formulün geliştirilmesi için derlenen metinler, metin sıklık çözümleyicisi yoluyla çözümlenmiş, en az sözcük uzunluğu 2.25 hece, en fazla sözcük uzunluğu 3.22 hece; en az cümle uzunluğu 6.83 sözcük, en fazla cümle uzunluğu 27.9 sözcük olmuştur. Formüllerin geliştirilmesinde yaygın olarak kullanılan ve metinlerin okunabilirliğiyle olan güçlü doğrusal olumlu veya olumsuz ilişkisi olduğu yapılan çalışmalarla ortaya konmuş, sözcük özelliği etmenini temsil ettiği düşünülen (1) dört ve daha fazla heceli sözcük oranı, (2) ortalama sözcük uzunluğu, (3) tekrarlanan sözcük gövde oranı değişkenleri belirlenmiştir. Yapılan ilişkisel eşlik çözümlemesi sonucu "Çıkartma Puanı" ile istatistiksel olarak anlamlı ilişkisi bulunan "Ortalama Sözcük Uzunluğu" ve "Ortalama Tümce Uzunluğu" değişkenleri regresyon çözümlemesine dâhil edilmiştir. Ortalama sözcük uzunluğu ve ortalama tümce uzunluğu değişkenlerine göre metinlerin okunabilirliğinin yordanmasına ilişkin regresyon çözümlemesi sonuçlarına göre, çıkartma puanının yordanmasına ilişkin regresyon denklemi $\mathrm{C} \mathrm{P}=118.823-25.987$ x OSU-0.971 x OTU şeklinde ortaya çıkmıştır.

\section{Verilerin Toplanması ve Analizi}

Araştırmada kullanılacak ders kitaplarına dijital ortamda ulaşılmasının ardından veri setine alınacak metinlerin belirlenmesi aşamasına geçilmiş, şiir ile tiyatro metinleri dışındaki öyküleyici ve bilgilendirici metinlerin değerlendirmeye alınmasına karar verilmiştir. $\mathrm{Bu}$ kararda şiir ve tiyatro türlerinin cümle kuruluşlarından dolayı okunabilirlik hesaplamalarının zor olması ve alanyazındaki çalışmalarda genelde bu iki türün okunabilirlik hesaplamalarında dikkate alınmıyor olması etkili olmuştur. Sonraki aşamada veri setinde yer alan metinlerin hece (seslem), kelime ve cümle sayıları belirlenmiştir. $\mathrm{Bu}$ işlemin gerçekleştirilmesinde iki boşluk arasındaki her öge kelime olarak kabul edilmiştir. Dilbilimsel açıdan cümle şeklinde görülen her öbek de cümle olarak nitelendirilmiştir. Nokta (.), iki nokta (:), üç nokta (...) ve soru işareti (?) ile biten kelime toplulukları cümle sayılırken virgülle bağlanan sıralı ve bağlı cümleler tek bir cümle olarak alınmıştır. Bu işlemin ardından ortalama kelime uzunluğunu bulmak için toplam hece sayısı toplam kelime sayısına, ortalama cümle uzunluğu bulmak için de toplam kelime sayısı toplam cümle sayısına bölünmüş, ulaşılan veriler Ateşman (1997) ile Çetinkaya-Uzun (2010) formüllerine yerleştirilmiş ve metinlerin okunabilirlik düzeyleri ayrı ayrı hesaplanmıştır. Son bölümde ise her metnin ortalama kelime ve cümle uzunluğu ile okunabilirlik düzeyine ilişkin bulgulara ait sıklık ve yüzde değerleri tablolar ve grafikler aracılı̆̆ıyla sunularak karşılaştırma ve yorumlamaya gidilmiştir.

Metinlerin okunabilirlik düzeylerini belirlemede kullanılan ve Ateşman (1997) tarafindan Flesch’ten Türkçeye uyarlanan formül şu şekildedir: 
"Okunabilirlik Puanı $=198.825-40.175 x A-2.610 x B "$

"A: Ortalama kelime uzunluğu”, "B: Ortalama cümle uzunluğu”

Çetinkaya (2010) tarafindan Türkçe metinler için geliştirilen Çetinkaya-Uzun okunabilirlik formülü ise şu şekildedir:

"Okunabilirlik Puant=118.823-25987 x OSU-0.971 x OTU"

"OSU= Ortalama sözcük uzunluğu”, "OTU= Ortalama tümce uzunluğu”

Veri setindeki metinlerin okunabilirlik puanlarının hesaplanması ve bu hesaplama sürecinde kullanılan okunabilirlik formülleri ile düzeylerinin belirlenmesine ilişkin bilgiler Tablo 3'te sunulmuştur.

Tablo 3

Ateşman ve Çetinkaya-Uzun'a Göre Okunabilirlik Puanlarl ve Düzeyleri

\begin{tabular}{|c|c|c|c|c|}
\hline \multicolumn{2}{|c|}{ Ateşman Okunabilirlik Formülü Düzeyleri } & \multicolumn{3}{|c|}{ Çetinkaya-Uzun Okunabilirlik Formülü Düzeyleri } \\
\hline Puan & Derece & Puan & Okuma Düzeyi & Sinıf Seviyesi \\
\hline $\begin{array}{c}90-100 \\
70-89\end{array}$ & $\begin{array}{l}\text { Çok kolay } \\
\text { Kolay }\end{array}$ & $51+$ & Bağımsız okuma & 5,6 ve 7. sinif \\
\hline $\begin{array}{l}50-69 \\
30-49\end{array}$ & $\begin{array}{l}\text { Orta güçlükte } \\
\text { Zor }\end{array}$ & $35-50$ & Eğitsel düzey & 8 ve 9. sinif \\
\hline $0-29$ & Çok zor & $0-34$ & Engelli düzey & 10,11 ve 12 . sinif \\
\hline
\end{tabular}

Tablo 3’te görüldüğü gibi Ateşman (1997) formülüne göre metinler çok zor (0-29 puan), zor (30-49 puan), orta güçlükte (50-69 puan), kolay (70-89 puan) ve çok kolay (90-100 puan) olmak üzere beş düzeye ayrılmaktadır. Çetinkaya-Uzun (2010) formülüne göre ise metinler, "engelli" (0-34 puan), "eğitsel” (35-50 puan) "bağımsız" (51+ puan) olmak üzere üç düzeye ayrılmaktadır.

Okunabilirlik düzeylerindeki temel çıkış noktası kelimelerdeki hece sayısı ile cümlelerdeki kelime sayısıdır. Ateşman'a (1997) göre Türkçe ve İngilizce metinlerdeki ortalama hece ve kelime uzunlukları Tablo 4'te gösterilmiştir.

Tablo 4

Türkçe/İngilizce Zorluk Derecesine Göre Kelime ve Cümle Uzunlukları

\begin{tabular}{ccccc}
\hline \multicolumn{2}{c}{ Türkçe } & Zorluk Derecesi & $\begin{array}{c}\text { İngilizce } \\
\text { Kelime Uzunluğu } \\
\text { (Seslem Sayısı) }\end{array}$ & $\begin{array}{c}\text { Cümle Uzunluğu } \\
\text { (Kelime Sayısı) }\end{array}$ \\
\hline (Seslem Sayısı) & $\begin{array}{c}\text { Cümle Uzunluğu } \\
\text { (Kelime Sayısı) }\end{array}$ & Kolay Metin & 1.3 & 10 \\
2.2 & 4 & Normal Metin & 1.5 & 17 \\
3.6 & 10 & Zor Metin & 1.8 & 27 \\
\hline
\end{tabular}

Tablo 4'te görüldüğ̈̈ üzere kelime uzunluğu ortalaması 2.2 hece ve cümle uzunluğu ortalaması dört kelime olan metinler kolay; kelime uzunluğu ortalaması 2.6 hece ve cümle uzunluğu ortalamas 10 kelime olan metinler normal ve kelime uzunluğu ortalaması üç hece ve cümle uzunluğu ortalamas1 30 kelime olan metinler zor olarak nitelendirilmektedir.

\section{Araştırma Etiği}

"Türk Dili ve Edebiyatı Ders Kitaplarındaki Metinlerin Okunabilirlik Düzeyleri” başlıklı çalışmanın yazım sürecinde bilimsel kurallara, etik ve alıntı kurallarına uyulmuş, toplanan veriler üzerinde herhangi bir tahrifat yapılmamış ve bu çalışma başka herhangi bir akademik yayın ortamına değerlendirme için gönderilmemiştir. Araştırma doküman incelemesine dayalı olarak gerçekleştirildiğinden etik kurul kararı zorunluluğu bulunmamaktadır. 


\section{Bulgular}

Bu bölümde araştırmada ulaşılan bulgulara yer verilmiştir. Bulgular alt problemlere dayalı olarak düzenlenmiş, her bir alt probleme ait bulgular, tablolar veya grafikler aracılığıyla sunulmuştur.

\section{Birinci Alt Probleme Yönelik Bulgular}

Araştırmanın “Türk Dili ve Edebiyat1 9. Sınıf Ders Kitabı'ndaki metinlerin okunabilirlikleri hangi düzeydedir?" şeklindeki birinci alt problemine ilişkin bulgular Tablo 5 'te gösterilmiştir.

Tablo 5

9. Sinıf Ders Kitabı 'ndaki Metinlerin Okunabilirlik Düzeyleri

\begin{tabular}{|c|c|c|c|c|c|c|c|c|}
\hline \multirow{2}{*}{ Tür } & \multirow{2}{*}{ Alt Tür } & \multirow{2}{*}{ Metnin Adı } & \multirow{2}{*}{ OKU } & \multirow{2}{*}{ OCU } & \multicolumn{2}{|c|}{ Ateşman } & \multicolumn{2}{|c|}{ Çetinkaya-Uzun } \\
\hline & & & & & OPU & Düzey & OPU & Düzey \\
\hline \multirow{6}{*}{ 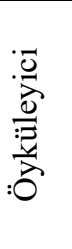 } & \multirow{2}{*}{ Hikâye } & Zincir & 2.63 & 12.04 & 61.74 & Orta & 38.78 & Eğitsel \\
\hline & & Son Kuşlar & 2.63 & 9.39 & 68.65 & Orta & 41.36 & Eğitsel \\
\hline & \multirow{2}{*}{ Masal/Fabl } & Tasa Kuşu & 2.20 & 17.48 & 64.81 & Orta & 44.67 & Eğitsel \\
\hline & & Şehzade İle Gulyabani & 2.46 & 11.40 & 70.24 & Kolay & 43.82 & Eğitsel \\
\hline & \multirow{2}{*}{ Roman } & Yaprak Dökümü & 2.58 & 9.67 & 72.34 & Kolay & 42.38 & Eğitsel \\
\hline & & Küçük Ağa & 2.50 & 8.73 & 75.60 & Kolay & 45.38 & Eğitsel \\
\hline \multirow{10}{*}{ 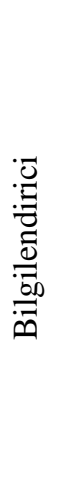 } & Biyografi/ & Cahit Sitk1 Taranc1 & 2.80 & 12.39 & 53.99 & Orta & 34.03 & Engelli \\
\hline & Otobiyografi & Cenevre & 2.60 & 9.74 & 68.94 & Orta & 41.80 & Eğitsel \\
\hline & \multirow{4}{*}{ Mektup } & Kardeş Mektupları & 2.84 & 6.00 & 69.06 & Orta & 39.19 & Eğitsel \\
\hline & & Güzel Yazılar-Mektuplar & 2.78 & 19.25 & 36.89 & Zor & 27.88 & Engelli \\
\hline & & Şikâyetname & 2.53 & 10.87 & 68.81 & Orta & 42.52 & Eğitsel \\
\hline & & $\begin{array}{l}\text { Ahmet Cevdet Paşa'nın Aile } \\
\text { Mektupları }\end{array}$ & 2.53 & 8.03 & 76.22 & Kolay & 45.27 & Eğitsel \\
\hline & \multirow{4}{*}{$\begin{array}{l}\text { Günlük/ } \\
\text { Blog }\end{array}$} & Günce & 2.62 & 6.75 & 75.95 & Kolay & 44.18 & Eğitsel \\
\hline & & Gündökümü & 2.60 & 6.85 & 76.49 & Kolay & 44.60 & Eğitsel \\
\hline & & Çay- Kahve & 2.89 & 8.56 & 60.37 & Orta & 35.41 & Eğitsel \\
\hline & & Ben Bugün & 2.21 & 5.59 & 94.45 & $\begin{array}{l}\text { Çok } \\
\text { kolay }\end{array}$ & 55.96 & Bağımsız \\
\hline
\end{tabular}

Tablo 5'te görüldüğü gibi Türk Dili ve Edebiyatı 9. Sınıf Ders Kitabı'ndaki öyküleyici metinlerin kelime uzunlukları ortalaması 2.20 ile 2.63; cümle uzunlukları ortalaması ise 8.73 ile 17.48 arasında değişmektedir. Bilgilendirici metinlerin kelime uzunlukları ortalamasının 2.21 ile 2.89; cümle uzunlukları ortalamasının da 5.59 ile 19.25 arasında değiştiği görülmektedir. Ateşman formülüne göre metinlerin okunabilirlik düzeyleri incelendiğinde 6 öyküleyici metnin 3'ünün (\%50) "kolay", 3'ünün (\%50) "orta güçlükte" düzeye sahip olduğu, buna karşın 10 bilgilendirici metnin 1'inin (\%10) "çok kolay", 3'ünün (\%30) "kolay", 5'inin (\%50) "orta güçlükte", 1'inin (\%10) de "zor" düzeye sahip olduğu tespit edilmiştir. Çetinkaya-Uzun formülüne göre ise öyküleyici metinlerin tamamı $(\% 100)$ "eğitsel”; bilgilendirici metinlerin de 2'si (\%20) “engelli", 7'si (\%70) "eğitsel”, 1'i de (\%10) "bağımsız" düzeydeki metinler olarak ortaya çıkmıştır.

\section{İkinci Alt Probleme Yönelik Bulgular}

Araştırmanın “Türk Dili ve Edebiyatı 10. Sınıf Ders Kitabı'ndaki metinlerin okunabilirlikleri hangi düzeydedir?” şeklindeki ikinci alt problemine ilişkin bulgular Tablo 6'da gösterilmiştir.

Tablo 6

10. Sinıf Ders Kitabı'ndaki Metinlerin Okunabilirlik Düzeyleri

\begin{tabular}{|c|c|c|c|c|c|c|c|c|}
\hline \multirow{2}{*}{ Tür } & \multirow{2}{*}{ Alt Tür } & \multirow{2}{*}{ Metnin Adı } & \multirow{2}{*}{ OKU } & \multirow{2}{*}{ OCU } & \multicolumn{2}{|c|}{ Ateşman } & \multicolumn{2}{|c|}{ Çetinkaya-Uzun } \\
\hline & & & & & OPU & Düzey & OPU & Düzey \\
\hline \multirow{5}{*}{ 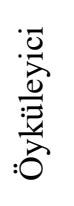 } & \multirow{5}{*}{ Hikâye } & Kerem ile Aslı & 2.19 & 8.95 & 87.48 & Kolay & 53.22 & Bağımsız \\
\hline & & Hayber Kalesi Cengi & 2.59 & 10.30 & 67.88 & Orta & 41.51 & Eğitsel \\
\hline & & Leyla vü Mecnun & 2.65 & 8.90 & 69.13 & Orta & 41.31 & Eğitsel \\
\hline & & Kediler & 2.76 & 14.87 & 49.13 & Zor & 32.66 & Engelli \\
\hline & & Yüksek Ökçeler & 2.62 & 7.10 & 75.03 & Kolay & 43.84 & Eğitsel \\
\hline
\end{tabular}




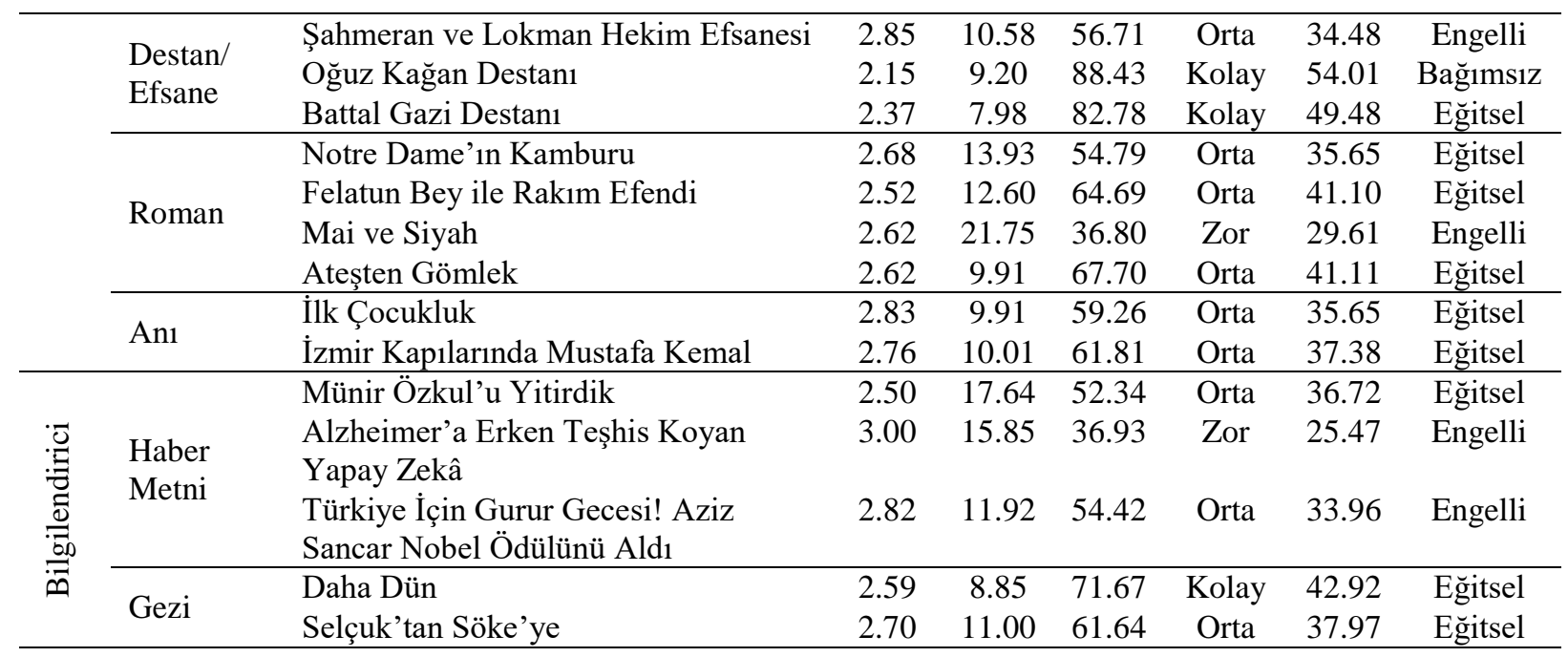

Tablo 6'da görüldüğü gibi Türk Dili ve Edebiyatı 10. Sınıf Ders Kitabı'ndaki öyküleyici metinlerin kelime uzunlukları ortalaması 2.15 ile 2.85; cümle uzunlukları ortalaması ise 7.10 ile 21.75 arasında değişmektedir. Bilgilendirici metinlerin kelime uzunlukları ortalamasının 2.50 ile 3.00; cümle uzunlukları ortalamasının da 8.85 ile 17.64 arasında değiştiği görülmektedir. Ateşman formülüne göre metinlerin okunabilirlik düzeyleri incelendiğinde 14 öyküleyici metnin 4'ünün (\%29) "kolay”, 8'inin (\%57) "orta güçlükte", 2'sinin (\%14) "zor" düzeye sahip olduğu, buna karşın 5 bilgilendirici metnin 1'inin (\%20) "kolay", 3'ünün (\%60) "orta güçlükte", 1'inin (\%20) de "zor" düzeye sahip olduğu tespit edilmiştir. Çetinkaya-Uzun formülüne göre ise öyküleyici metinlerin 3’ü (\%21) "engelli”, 9'u (\%65) "eğitsel”, 2'si (\%14) "bağımsız"; bilgilendirici metinlerin de 2'si (\%40) "engelli”, 3'ü (\%60) "eğitsel" düzeydeki metinler olarak ortaya çıkmıştır.

\section{Üçüncü Alt Probleme Yönelik Bulgular}

Araştırmanın “Türk Dili ve Edebiyat1 11. Sınıf Ders Kitabı'ndaki metinlerin okunabilirlikleri hangi düzeydedir?” şeklindeki üçüncü alt problemine ilişkin bulgular Tablo 7'de gösterilmiştir.

Tablo 7

11. Sinıf Ders Kitabi'ndaki Metinlerin Okunabilirlik Düzeyleri

\begin{tabular}{|c|c|c|c|c|c|c|c|c|}
\hline \multirow{2}{*}{ Tür } & \multirow{2}{*}{ Alt Tür } & \multirow{2}{*}{ Metnin Adı } & \multirow{2}{*}{ OKU } & \multirow{2}{*}{ OCU } & \multicolumn{2}{|c|}{ Ateşman } & \multicolumn{2}{|c|}{ Çetinkaya-Uzun } \\
\hline & & & & & OPU & Düzey & OPU & Düzey \\
\hline \multirow{10}{*}{ 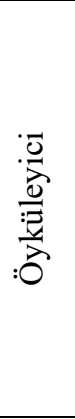 } & \multirow{5}{*}{ Hikâye } & Kamyon & 2.69 & 12.85 & 57.21 & Orta & 36.44 & Eğitsel \\
\hline & & Pazarlık & 2.25 & 7.64 & 88.49 & Kolay & 56.93 & Bağımsız \\
\hline & & Oğlumuz & 2.53 & 6.15 & 81.13 & Kolay & 47.10 & Eğitsel \\
\hline & & Koca Öküzün Ölümü & 2.56 & 6.00 & 80.31 & Kolay & 46.47 & Eğitsel \\
\hline & & Odalardan Biri & 2.58 & 4.88 & 82.43 & Kolay & 47.03 & Eğitsel \\
\hline & \multirow{5}{*}{ Roman } & Yaban & 2.52 & 8.23 & 76.10 & Kolay & 45.34 & Eğitsel \\
\hline & & Huzur & 2.70 & 10.29 & 63.49 & Orta & 38.66 & Eğitsel \\
\hline & & Murtaza & 2.54 & 6.07 & 80.93 & Kolay & 46.92 & Eğitsel \\
\hline & & Tutunamayanlar & 2.58 & 6.07 & 79.33 & Kolay & 45.88 & Eğitsel \\
\hline & & Yaşlı Adam ve Deniz & 2.60 & 8.14 & 73.12 & Kolay & 43.35 & Eğitsel \\
\hline \multirow{7}{*}{ 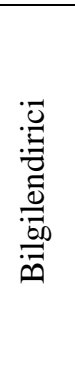 } & \multirow{3}{*}{ Makale } & $\begin{array}{l}\text { Dünyada ve Türkiye’de Rüzgâr } \\
\text { Enerjisi }\end{array}$ & 2.86 & 21.47 & 27.88 & Çok zor & 23.65 & Engelli \\
\hline & & $\begin{array}{l}\text { İnsan-Doğa İlişkisi Bağlamında Çevre } \\
\text { Sorunları ve Felsefe }\end{array}$ & 2.87 & 20.88 & 29.02 & Çok zor & 23.96 & Engelli \\
\hline & & Hayat ve Edebiyat & 2.73 & 24.00 & 26.50 & Çok zor & 24.57 & Engelli \\
\hline & \multirow{4}{*}{$\begin{array}{l}\text { Sohbet/ } \\
\text { F1kra }\end{array}$} & Zenginlerin İftar Sofralarında & 2.56 & 12.53 & 63.27 & Orta & 40.13 & Eğitsel \\
\hline & & İstemeye Dair & 2.72 & 13.20 & 55.09 & Orta & 35.32 & Eğitsel \\
\hline & & Mizahta Ehliyet & 2.63 & 14.52 & 56.26 & Orta & 36.38 & Eğitsel \\
\hline & & 80 Gün 64 Saat & 2.72 & 11.88 & 58.54 & Orta & 36.60 & Eğitsel \\
\hline
\end{tabular}




\begin{tabular}{llcccccc}
\hline \multirow{2}{*}{ Eleştiri } & Gustave Flaubert Nazariyat-1 Edebiye & 2.77 & 15.54 & 46.98 & Zor & 31.75 & Engelli \\
& ve Felsefesi & & & & & & \\
& Rabia Hatun Şiirleri & 2.59 & 15.02 & 55.57 & Orta & 36.93 & Eğitsel \\
& $\begin{array}{l}\text { Peyami Safa'nın Yalnızız } \\
\text { Romanındaki Anlatım Sanatı }\end{array}$ & 2.77 & 14.10 & 50.74 & Orta & 33.14 & Engelli \\
\hline \multirow{2}{*}{ Mülakat } & & & & & & & \\
& Sami Paşazade Sezai Bey & 2.55 & 10.20 & 69.75 & Orta & 42.65 & Eğitsel \\
& Abdülhak Şinasi Hisar & 2.79 & 10.03 & 60.55 & Orta & 36.58 & Eğitsel \\
& Traktörcü & 2.45 & 5.63 & 85.70 & Kolay & 49.68 & Eğitsel \\
\hline
\end{tabular}

Tablo 7'de görüldüğü gibi Türk Dili ve Edebiyatı 11. Sınıf Ders Kitabı'ndaki öyküleyici metinlerin kelime uzunlukları ortalaması 2.25 ile 2.70; cümle uzunlukları ortalaması ise 4.88 ile 12.85 arasında değişmektedir. Bilgilendirici metinlerin kelime uzunlukları ortalamasının 2.45 ile 2.87; cümle uzunlukları ortalamasının da 5.63 ile 24.00 arasında değiştiği görülmektedir. Ateşman formülüne göre metinlerin okunabilirlik düzeyleri incelendiğinde 10 öyküleyici metnin 8'inin (\%80) "kolay", 2'sinin (\%20) "orta güçlükte" düzeye sahip olduğu, buna karşın 13 bilgilendirici metnin 1'inin (\%8) "kolay", 8'inin (\%62) "orta güçlükte", 1'inin (\%8) "zor", 3’ünün (\%22) de "çok zor" düzeye sahip olduğu tespit edilmiştir. Çetinkaya-Uzun formülüne göre ise öyküleyici metinlerin 9'u (\%90) "eğitsel”, 1’i (\%10) "bağımsız"; bilgilendirici metinlerin de 5'i (\%39) "engelli”, 8'i (\%61) "eğitsel" düzeydeki metinler olarak ortaya çıkmıştır.

\section{Dördüncü Alt Probleme Yönelik Bulgular}

Araştırmanın "Türk Dili ve Edebiyatı 12. Sınıf Ders Kitabı'ndaki metinlerin okunabilirlikleri hangi düzeydedir?” şeklindeki dördüncü alt problemine ilişkin bulgular Tablo 8'de gösterilmiştir.

Tablo 8

12. Sinıf Ders Kitabı'ndaki Metinlerin Okunabilirlik Düzeyleri

\begin{tabular}{|c|c|c|c|c|c|c|c|c|}
\hline \multirow{2}{*}{ Tür } & \multirow{2}{*}{ Alt Tür } & \multirow{2}{*}{ Metnin Adı } & \multirow{2}{*}{ OKU } & \multirow{2}{*}{ OCU } & \multicolumn{2}{|c|}{ Atessman } & \multicolumn{2}{|c|}{ Cetinkaya-Uzun } \\
\hline & & & & & OPU & Düzey & OPU & Düzey \\
\hline \multirow{10}{*}{ 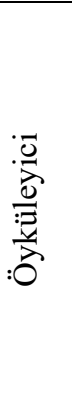 } & \multirow{4}{*}{ Hikâye } & Bir Saatlik Telaki & 2.62 & 6.68 & 76.13 & Kolay & 44.25 & Eğitsel \\
\hline & & Demiryolu Hikâyecileri-Bir Rüya & 3.11 & 8.00 & 53.00 & Orta & 30.23 & Engelli \\
\hline & & Karanfilsiz & 2.61 & 5.60 & 79.35 & Kolay & 45.56 & Eğitsel \\
\hline & & Parasız Yatılı & 2.65 & 6.32 & 75.86 & Kolay & 43.82 & Eğitsel \\
\hline & \multirow{6}{*}{ Roman } & Üç İstanbul & 2.72 & 9.49 & 64.78 & Orta & 38.92 & Eğitsel \\
\hline & & Bereketli Topraklar Üzerinde & 2.50 & 5.97 & 82.80 & Kolay & 48.06 & Eğitsel \\
\hline & & Aylak Adam & 2.59 & 5.06 & 81.56 & Kolay & 46.60 & Eğitsel \\
\hline & & Sevgili Arsız Ölüm & 2.67 & 7.80 & 71.20 & Kolay & 41.86 & Eğitsel \\
\hline & & Selvi Boylum Al Yazmalım & 2.59 & 6.05 & 78.98 & Kolay & 45.64 & Eğitsel \\
\hline & & Bülbülü Öldürmek & 2.66 & 13.59 & 56.49 & Orta & 36.50 & Eğitsel \\
\hline \multirow{8}{*}{ 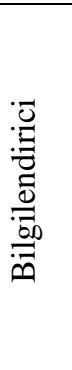 } & \multirow{4}{*}{ Deneme } & Doğruluk Kaygısı & 2.70 & 9.25 & 66.21 & Orta & 39.67 & Eğitsel \\
\hline & & Karalama Defteri & 2.85 & 13.45 & 49.22 & Zor & 31.70 & Engelli \\
\hline & & Kitap & 2.77 & 6.27 & 71.17 & Kolay & 40.75 & Eğitsel \\
\hline & & Sabaha Doğru & 3.44 & 6.15 & 44.57 & Zor & 23.45 & Engelli \\
\hline & \multirow{4}{*}{ Söylev } & Nutuk & 2.68 & 13.17 & 56.78 & Orta & 36.39 & Eğitsel \\
\hline & & Başkumandan Muharebesi & 2.55 & 11.55 & 66.23 & Orta & 41.34 & Eğitsel \\
\hline & & Kök Türk Kitabeleri & 2.22 & 14.14 & 72.73 & Kolay & 47.40 & Eğitsel \\
\hline & & $\begin{array}{l}\text { Alparslan'ın Malazgirt Meydan } \\
\text { Muharebesindeki Nutku }\end{array}$ & 2.57 & 16.87 & 51.54 & Orta & 35.65 & Eğitsel \\
\hline
\end{tabular}

Tablo 8'de görüldüğü gibi Türk Dili ve Edebiyatı 12. Sınıf Ders Kitabı'ndaki öyküleyici metinlerin kelime uzunlukları ortalaması 2.50 ile 3.11; cümle uzunlukları ortalaması ise 5.06 ile 13.59 arasında değişmektedir. Bilgilendirici metinlerin kelime uzunlukları ortalamasının 2.22 ile 3.44; cümle uzunlukları ortalamasının da 6.15 ile 16.87 arasında değiştiği görülmektedir. Ateşman formülüne göre metinlerin okunabilirlik düzeyleri incelendiğinde 10 öyküleyici metnin 7'sinin (\%70) "kolay", 3'ünün (\%30) "orta güçlükte" düzeye sahip olduğu, buna karşın 8 bilgilendirici metnin 2'sinin (\%25) "kolay", 4'ünün (\%50) "orta güçlükte", 2'sinin $(\% 25)$ de "zor" düzeye sahip olduğu tespit edilmiştir. 
Çetinkaya-Uzun formülüne göre ise öyküleyici metinlerin 1'i (\%10) "engelli” diğerleri (\%90) "eğitsel"; bilgilendirici metinlerin de 2'si (\%25) "engelli", diğerleri (\%75) "eğitsel" düzeydeki metinler olarak ortaya çıkmıştır.

\section{Beşinci Alt Probleme Yönelik Bulgular}

Araştırmanın "Türk Dili ve Edebiyatı ders kitaplarındaki metinlerin ortalama kelime ve cümle uzunlukları ile okunabilirlik puanlarının sınıf seviyesine ve metin türüne göre dağılımı nasıldır?" şeklindeki beşinci alt problemine ilişkin bulgular aşağıdaki grafiklerde gösterilmiştir.

Ders kitaplarındaki metinlerin ortalama kelime ve cümle uzunluklarının sınıf seviyesine ve metin türüne göre dağılımına Grafik 1'de yer verilmiştir.

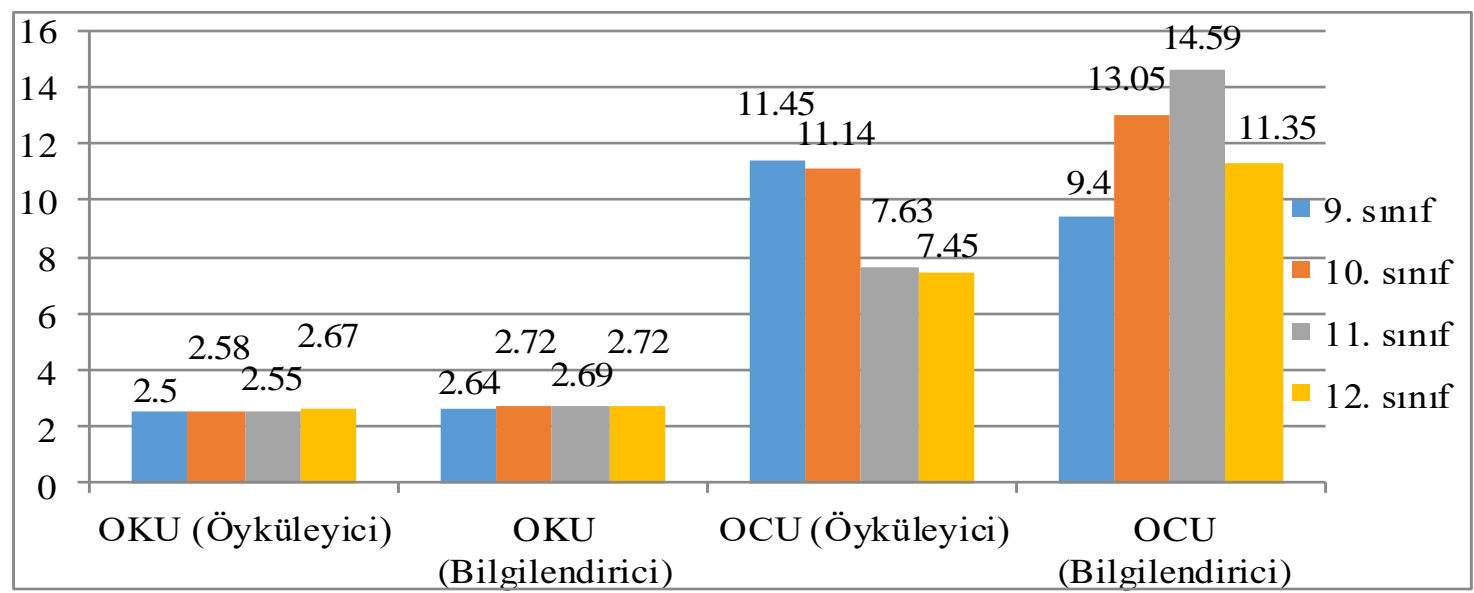

Grafik 1. Ortalama Kelime ve Cümle Uzunluklanı

Grafik 1'e göre sınıf seviyelerine göre bilgilendirici metinlerin ortalama kelime uzunluklarının öyküleyici metinlerin ortalama kelime uzunluklarından daha fazla olduğu görülmektedir. Hem öyküleyici hem de bilgilendirici metinlerin ortalama kelime uzunlukları ise sınıf düzeylerine göre benzer bir görünüm arz etmektedir. Her iki metin türünde de ortalama kelime uzunlukları en az 9 ve 11. sınıf, en fazla 10 ve 12. sınıf metinlerinde karşımıza çıkmaktadır.

Sınıf seviyelerine göre ortalama cümle uzunluklarına bakıldığında 9. sınıf kitabındaki metinler dışında bilgilendirici metinlerin öyküleyici metinlerden daha uzun cümlelere sahip olduğu görülmektedir. Öyküleyici metinlerin ortalama cümle uzunlukları sınıf seviyesi artıkça düşmekte, bilgilendirici metinlerinki ise 9. sinıftan 11. sınıfa kadar kademeli olarak artmakta, 12. sinıfta tekrar düşüş göstermektedir.

Ders kitaplarındaki metinlerin Ateşman formülüne göre okunabilirlik puan ortalamalarının sınıf seviyesine ve metin türüne göre dağılımı Grafik 2'de gösterilmiştir.

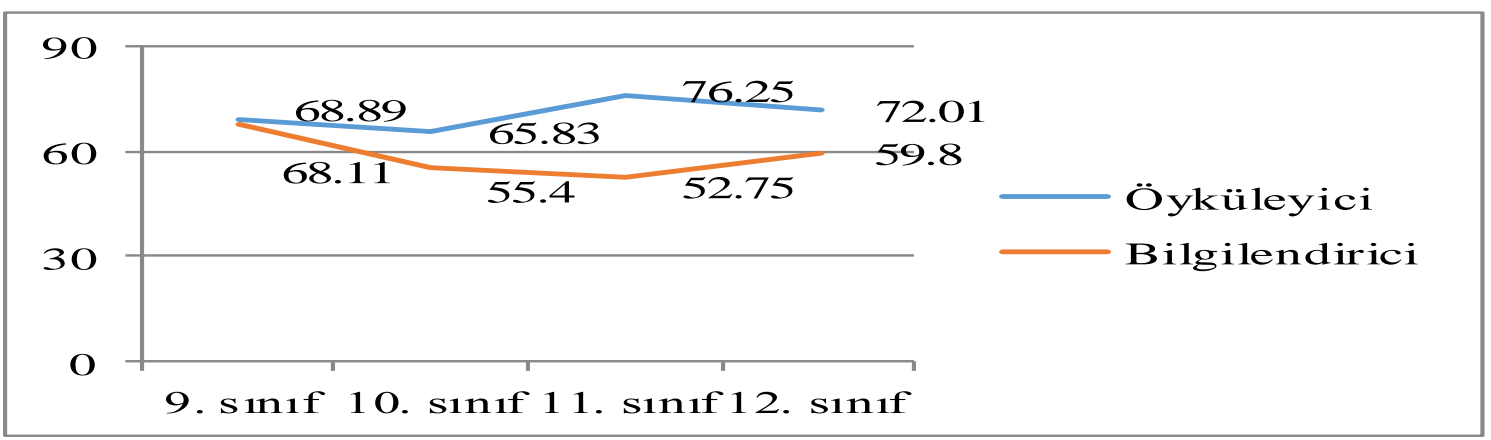

Grafik 2. Ateşman Formülüne Göre Okunabilirlik Puan Ortalamaları 
Grafik 2'de görüldüğü üzere 9 ve 10. sınıftaki öyküleyici metinlerin puan ortalamaları "orta güçlükte", 11 ve 12. sinıftaki öyküleyici metinlerin puan ortalamaları ise "kolay" düzeye karşıllk gelmektedir. Ortalamalara bakıldığında okunabilirliği en kolay metinlerin 11, en zor metinlerin 10. sınıfta yer aldığı söylenebilir. Bilgilendirici metinlerin puan ortalamaları dikkate alındığında bütün sınıf seviyelerindeki metinler "orta güçlükte" düzeye karşılık gelmektedir. Ortalamalara bakıldığında ise okunabilirliği en kolay metinlerin 9, en zor metinlerin 11. sınıfta bulunduğu görülmektedir. Her iki metin türünün puan ortalamalarının en yakın olduğu sınıf seviyesi 9, en uzak olduğu sınıf seviyesi 11. siniftır.

Ders kitaplarındaki metinlerin Çetinkaya-Uzun formülüne göre okunabilirlik puan ortalamalarının sınıf seviyesine ve metin türüne göre dağılımı Grafik 3’te gösterilmiștir.

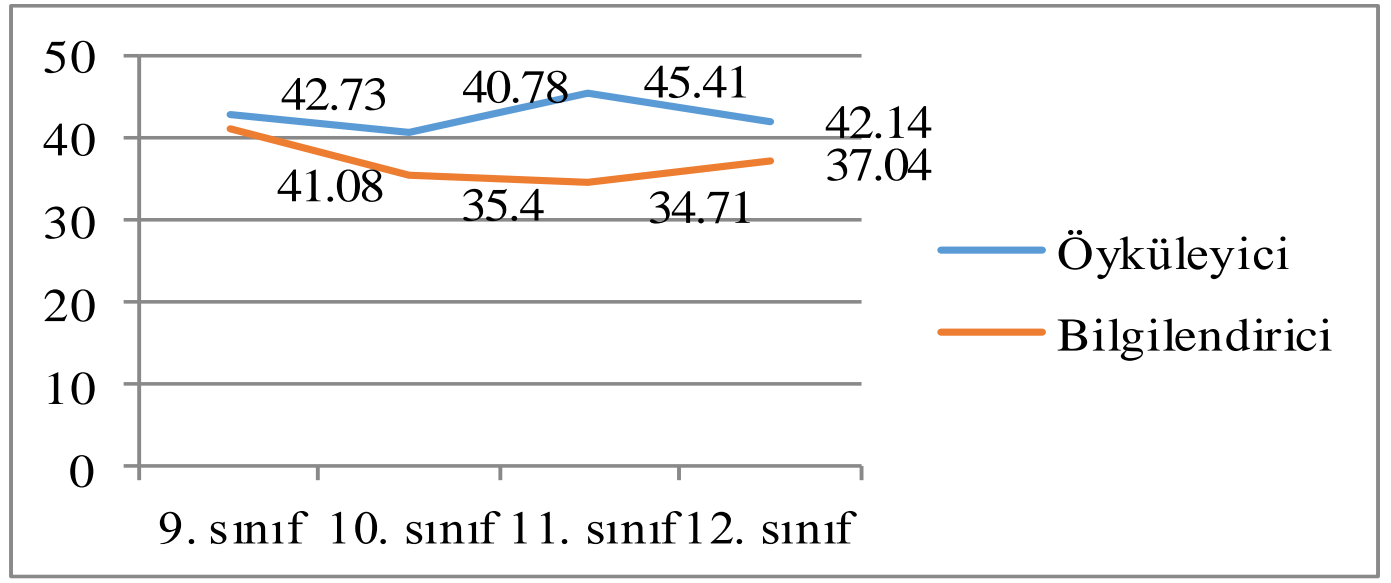

Grafik 3. Çetinkaya-Uzun Formülüne Göre Okunabilirlik Puan Ortalamaları

Grafik 3'te görüldüğü gibi öyküleyici metinlerin puan ortalamaları bütün sınıf seviyelerinde "eğitsel" düzeye karşılık gelirken bilgilendirici metinlerin puan ortalamaları 11. sınıf hariç (engelli düzeyi) yine "eğitsel" düzeydedir. Ayrıca sınıf seviyelerine göre metin türleri arasındaki puan farkı durumunun Ateşman formülüne benzer olduğu görülmektedir.

\section{Altıncı Alt Probleme Yönelik Bulgular}

Araştırmanın "Okunabilirlik düzeylerinin metin türlerine göre dağılımı nasıldır?" şeklindeki altıncı alt problemine ilişkin bulgular farklı iki formüle göre Grafik 4 ve Grafik 5'te gösterilmiştir.

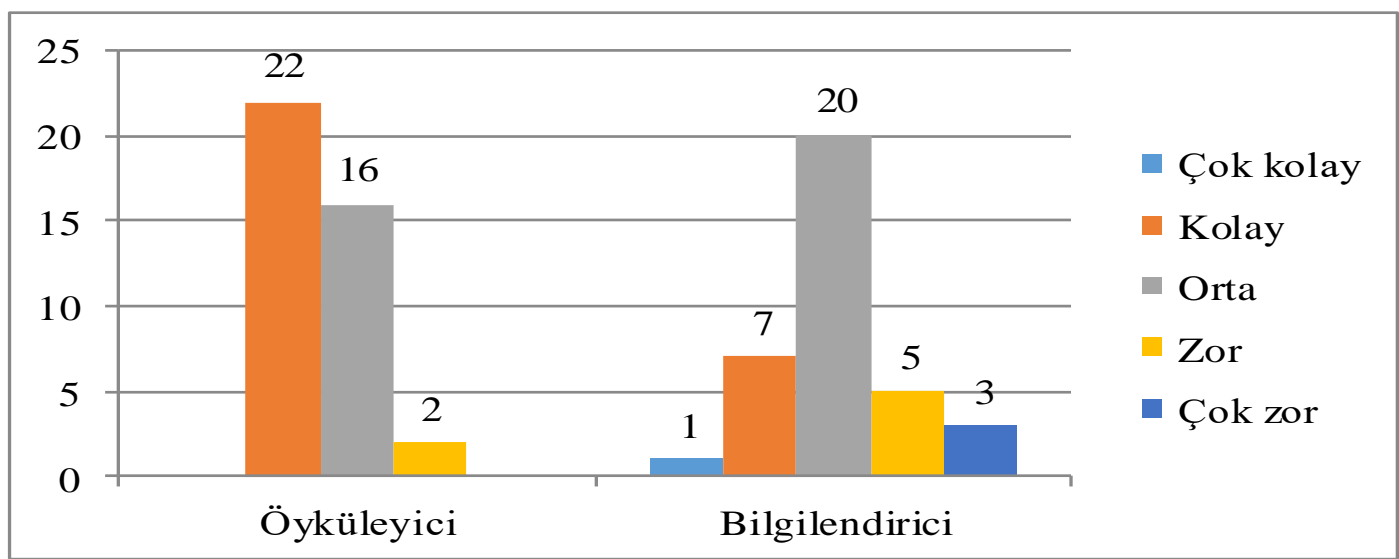

Grafik 4. Ateşman Formülüne Göre Okunabilirlik Düzeylerinin Metin Türlerine Dağılımı 
Grafik 4'te görüldüğü üzere Ateşman formülündeki okunabilirlik düzeyleri dikkate alındığında öyküleyici metinlerin 22'si (\%55) "kolay", 16's1 (\%40) "orta güçlükte", 2'si (\%5) de "zor" düzeydeki metinlerden oluşmaktadır. Bilgilendirici metinlerin ise 20'si (\%56) "orta güçlükte", 7'si (\%19) "kolay”, 5'i (\%15) "zor”, 3’ü (\%8) “çok zor”, 1'i (\%3) de "çok kolay” düzeydeki metinlerdir. Buna göre öyküleyici metinlerin çoğu "kolay" (\%55), bilgilendirici metinlerin çoğu ise "orta güçlükte"ki (\%56) metinlerdir.

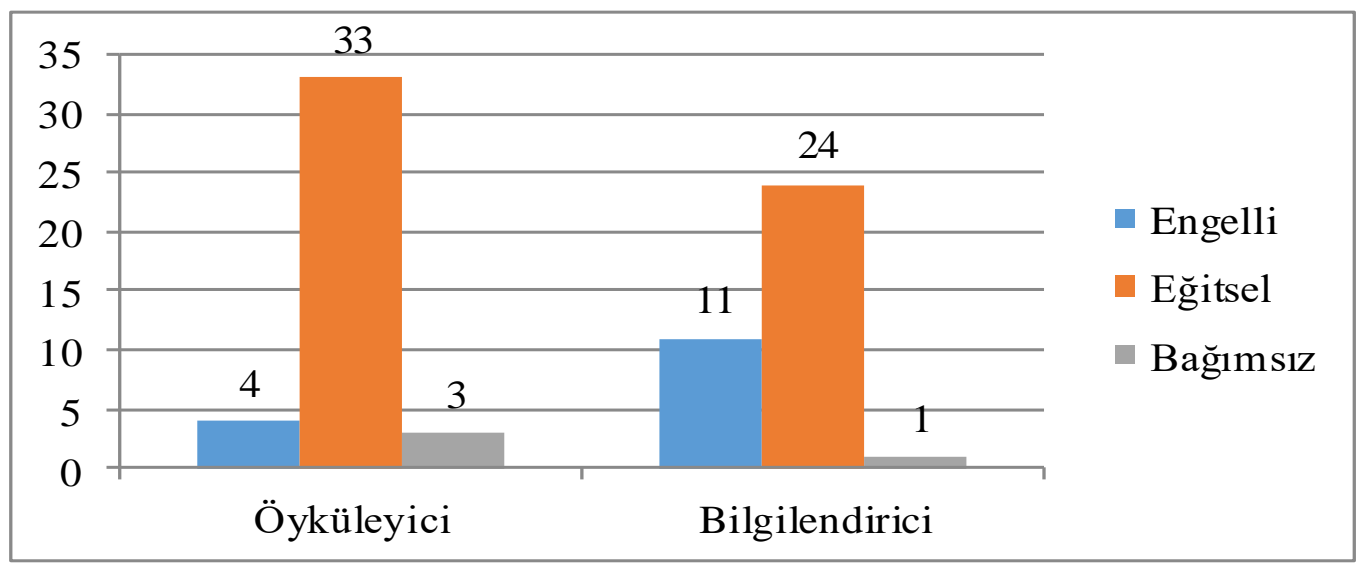

Grafik 5. Çetinkaya-Uzun Formülüne Göre Okunabilirlik Düzeylerinin Metin Türlerine Dağglımı

Grafik 5'te görüldüğü gibi Çetinkaya-Uzun formülündeki okunabilirlik düzeyleri dikkate alındığında öyküleyici metinlerin 33'ü (\%83) "eğitsel”, 4'ü (\%10) "engelli”, 3’ü (\%6) de "bağımsız" düzeyken bilgilendirici metinlerin 24'ü (\%66) "eğitsel", 11'i (\%31) "engelli", 1'i (\%3) de "bağımsı"” düzeydir. Buna göre hem öyküleyici hem de bilgilendirici metinlerin büyük bir kısmının "eğitsel" düzeye sahip olduğu görülmektedir.

\section{Sonuç, Tartışma ve Öneriler}

$\mathrm{Bu}$ araştırmada ortaöğretim Türk Dili ve Edebiyatı ders kitaplarında yer alan öyküleyici ve bilgilendirici metinlerin okunabilirlik düzeylerinin belirlenmesi amaçlanmış, ulaşılan sonuçlara ve bu sonuçların alanyazındaki farklı araştırmalarla ilişkisine bu bölümde değinilmiştir.

Sınıf seviyelerine ve metin türlerine göre okunabilirlik düzeylerine (Ateşman formülüne göre) bakıldığında 9. sınıf kitabındaki öyküleyici metinlerde "kolay" ve "orta güçlükte" metinlerin eşit şekilde (\%50) dağıtıldığı, bilgilendirici metinlerde ise dört farklı düzeyin yer aldığı ve "orta güçlükte" metinlerin ağırlıkta olduğu (\%50) belirlenmiştir. 10. sınıf kitabındaki öyküleyici metinlerde üç farklı düzeyin bulunduğu, orta güçlükteki metinlerin ağırlıklı (\%57) olduğu; yine üç farklı düzeyin yer aldığı bilgilendirici metin kategorisinde de "orta güçlükte" metinlerin daha fazla (\%60) yer aldığı tespit edilmiştir. 11. sınıf ders kitabında öyküleyici metinlerin iki farklı düzeyi barındırdığı ve "kolay" metinlerin belirgin şekilde (\%80) öne çıktığı; bilgilendirici metinlerin ise dört farklı düzeyi içerdiği ve "orta güçlükte" metinlerin daha fazla (\%62) kullanıldığı belirlenmiştir. 12. sınıf ders kitabındaki öyküleyici metinlerde iki farklı düzeyin yer aldığı ve "kolay" metinlerin ağırlıkta (\%70) olduğu; üç farklı düzeydeki bilgilendirici metinlerde de "orta güçlükte" metinlerin öne çıtığ (\%50) görülmüştür. Buna göre öyküleyici metinlerde 9. sınıfta "kolay" ve "orta güçlükte" metinler eşit sayıdayken 10. sınıfta "orta güçlükte", 11 ve 12. sınıfta ise "kolay" metinlerin ağırlıklı olduğu tespit edilmiştir. Bu durumda sınıf seviyesi arttıkça öyküleyici metinlerin daha kolay metinlerden seçildiği söylenebilir. Normal şartlar altında sınıf seviyesi arttıkça öğrencilerin daha zor metinlerle karşılaşmaları beklendiğinden ortaya çıkan bu sonuç, hazırlanan kitapların bir eksikliği olarak nitelendirilebilir. Bilgilendirici metinlerde ise tüm sınıf seviyelerinde "orta güçlükte" metinlere daha fazla yer ayrılmıştır. Bu düzeydeki metinlerin oranı 9. sınıftan 11. sınıfa kadar kademeli olarak artış göstermiş ancak 12. sınıfta tekrar 9. sınıf kitabındaki orana düşmüştür. Farklı düzeydeki metinlere yer verilme durumuna göre kitaplar incelendiğinde 10. sınıftaki öyküleyici metinlerin üç, diğer sınıf 
seviyelerindeki öyküleyici metinlerin iki farklı düzeyi; bilgilendirici metinlerde ise 9 ve 11. sınıftaki metinlerin dört, 10 ve 12. sınıftaki metinlerin üç farklı düzeyi içerdiği belirlenmiştir. Buna göre bilgilendirici metinlerde okunabilirlik düzeyi çeşitliliğinin daha zengin olduğu şeklinde bir yorum yapılabilir. Farklı sınıf seviyelerindeki metinlerin incelendiği araştırmalarda da (Arı ve Okur, 2013; Baki, 2019; Demir ve Çeçen, 2013; Özçetin ve Karakuş, 2020; Özdemir, 2016) bu yargıyı destekleyen bulgular elde edilmiştir.

Okunabilirlik düzeylerinin Çetinkaya-Uzun formülüne göre incelenmesi neticesinde 9. sinıf kitabındaki öyküleyici metinlerin tamamının, bilgilendirici metinlerin de \%70'inin "eğitsel” düzeyde olduğu ortaya çıkmıştır. Formüle göre bu düzeyin 8 ve 9. sınıfa karş1lık geldiği düşünüldügünde kitaplardaki metinlerin büyük oranda sınıf seviyesine uygun seçildiği söylenebilir. 10. sınıftaki öyküleyici metinlerin $\% 65$ 'i, bilgilendirici metinlerin $\% 60$ '1; 11 . sinıftaki öyküleyici metinlerin $\% 90$ ' 1 , bilgilendirici metinlerin \%61'i ve 12 . sinıftaki öyküleyici metinlerin \%90'1, bilgilendirici metinlerin de \%75'i "eğitsel” düzeydeki metinlerden oluşmaktadır. Bu sonuç, bu sınıf seviyeleri için hazırlanmış kitaplardaki metinlerin genel olarak seviyenin altında bir okunabilirlik düzeyine sahip olduğunu göstermektedir. Zira formüle göre bu sınıf düzeyleri için ifade edilmiş olan "engelli" düzey metinlerin öyküleyici metinler içindeki oranı \%17, bilgilendirici metinler içindeki oranı ise \%37'de kalmıştır.

Sınıf seviyelerine ve metin türlerine göre ortalama kelime uzunluklarına bakıldığında hem bilgilendirici hem de öyküleyici metinlerde ortalama kelime uzunlukları 9. ve 11. sinıfta, 10 ve 12 . sınıfa göre daha kısadır. Sınıf seviyeleri kendi içinde değerlendirildiğinde ise bütün sınıflarda bilgilendirici metinlerin öyküleyici metinlerden daha uzun kelime ortalamasına sahip olduğu ortaya çıkmıştır. Sınıf seviyelerine göre ortalama cümle uzunluklarına bakıldığında 9. sınıf kitabındaki metinler dişında bilgilendirici metinlerin öyküleyici metinlerden daha uzun cümlelere sahip olduğu görülmektedir. Çeşitli araştırmalarda da (Baş ve İnan-Yıldız, 2015; Çiftçi, Çeçen ve Melanlıoğlu, 2007; Özçetin ve Karakuş, 2020; Özdemir, 2016) bilgilendirici metinlerin ortalama kelime ve cümle uzunluklarının öyküleyici metinlerden daha fazla olduğu tespit edilmiştir. Erdem'in (2011) araştırmasında ise Dil ve Anlatım ders kitaplarındaki bilgilendirici metinlerin ortalama kelime uzunlukları öyküleyici metinlerden fazlayken ortalama cümle uzunlukları tüm sınıf seviyelerinde daha kısa olarak ortaya çıkmıştır. Özdemir'e (2016) göre türler arasındaki bu farklılık bilgilendirici metinlerin uzun açıklamalarla, öyküleyici metinlerin günlük dilde kullanılan kısa cümle yapılarıyla oluşturulmasından kaynaklanmakta, ayrıca çocuk edebiyatı ilkelerinin yazarlar tarafindan benimsenmesi ve yazarların öyküleyici metinleri çocuğa göre oluşturmaları bu metinlerin daha kısa sözcük ve cümle yapısıyla oluşturulmasında etkili olmaktadır. Araştırma bulgularına göre öyküleyici metinlerin ortalama cümle uzunlukları sınıf seviyesi artıkça düşmekte, bilgilendirici metinlerinki ise 9 . sınıftan 11. sınıfa kadar kademeli olarak artmakta, 12. sinıfta tekrar düşüş göstermektedir. Bu sonucun, İskender'in (2013) ortaokul Türkçe ders kitaplarını incelediği ve 5. sinıftan 8. sınıfa doğru kelime ve cümle uzunluğu ortalamasının anlamlı bir şekilde farklılaşmadığı şeklindeki yargısıyla benzer olduğu düşünülmektedir. Ayrıca öyküleyici metinlerin sınıf seviyesi arttıkça daha kolay metinlerden oluşmuş olmasının cümle ortalamalarının sınıf seviyesi arttıkça daha kısa olmasıyla paralel olduğu söylenebilir. Yine 12. sinıfa kadar bilgilendirici metin kategorisinde "orta güçlükte" metinlerin oran olarak artmasının cümle uzunluklarının artışıyla bağlantılı olduğu düşünülmektedir.

Metinlerin okunabilirlik puanlarının ortalamasının sınıf seviyesine göre dağılımı incelendiğinde öyküleyici metinlerde en kolay metinler 11, bilgilendirici metinlerde ise 9. sinıftadır. Buna karş1lk öyküleyici metinlerde en zor metinler 10, bilgilendirici metinlerde ise 11. sınıftadır. Buna göre 11. sınıf ders kitabının öyküleyici türde daha kolay, bilgilendirici türde daha zor metinleri içerdiği söylenebilir. Bundan dolayı da 11. sınıf, metin türlerine göre puan ortalaması farkının (Ateşman formülü) en fazla olduğu (23.5) sınıf seviyesidir. Farkın en az olduğu (0.75) kitap ise 9. sınıf ders kitabı olarak belirlenmiştir. Erdem'in (2011) Dil ve Anlatım ders kitaplarını ele aldığı araştırmaya göre okunabilirlik puan ortalamalarına göre hem öyküleyici hem de bilgilendirici metinlerde en kolay metinler 9. sinıfta, öyküleyici metinlerde en zor metinler 10. sinıfta, bilgilendirici metinlerde ise 11. sınıfta kullanılmıştır. Buna göre metinlerin okunabilirlik bakımından zorluk seviyelerinin genel olarak sınıf seviyelerine göre belirgin şekilde artmadığı söylenebilir. Bora (2019) tarafından ortaokul Türkçe ders kitaplarındaki bilgilendirici ve öyküleyici metinlerin, Şakiroğlu (2020) tarafından ortaokul Türkçe 
ders kitaplarındaki öyküleyici metinlerin ve Zorbaz (2007) tarafından ilk ve ortaokul Türkçe ders kitaplarındaki masalların incelendiği araştırmalarda da benzer sonuçlara ulaşıldığı görülmektedir.

Her iki formülden hareketle okunabilirlik düzeylerinin metin türlerine göre dağılımı ele alındığında öyküleyici metinlerde üç farklı (kolay, orta güçlükte, zor) düzeyin (Ateşman formülüne göre) yer aldığ 1 , metinlerin \%55'inin "kolay", \%40'ının "orta güçlükte", \%5'inin de "zor" düzeydeki metinlerden oluştuğu belirlenmiştir. Formüldeki bütün düzeyleri örneklendiren metinlerin kullanıldığ bilgilendirici metinlerin ise \%56's1 "orta güçlükte", \%19'u "kolay", \%15'i "zor", \%8'i "çok zor", \%3'ü de "çok kolay" düzeydeki metinlerdir. Buna göre öyküleyici metinlerin çoğu "kolay" (\%55), bilgilendirici metinlerin çoğu ise "orta güçlükte" (\%56) metinlerdir. Bu bağlamda öyküleyici metinlerin okunabilirlik düzeyinin bilgilendirici metinlere göre daha kolay olduğu ifade edilebilir. Ortaokul 6, 7 ve 8. sınıf Türkçe ders kitaplarındaki metinlerin okunabilirliğini inceleyen Arı ve Okur'un (2013) araştırmasında da öyküleyici metinlerde yoğunluğun "kolay", bilgilendirici metinlerde ise "orta güçlükte" olduğu ortaya çıkmıştır. Özdemir'in (2016) ortaokul 5. sınıf Türkçe ders kitabındaki metinleri incelediği araştırmada da öyküleyici metinlerin \%71.4'ü "kolay", bilgilendirici metinlerin \%58.3'ü "orta güçlükte" metinler olarak belirlenmiştir. Benzer şekilde Özçetin ve Karakuş'un (2020) araştırmasında da 5. sınıf Türkçe ders kitabındaki öyküleyici metinlerin genelde (\%73.33) "kolay", bilgilendirici metinlerin ise genelde (\%63.63) "orta güçlükte" olduğu tespit edilmiştir. 6. sınıf Türkçe ders kitaplarını inceleyen Çiftçi, Çeçen ve Melanlığlu (2007) ile 2. sınıf Türkçe ders kitaplarını inceleyen Baş ve İnan-Yıldız'ın (2015) araştırmalarında da benzer bulgulara ulaşılmıştır. Bu sonuçlardan farklı olarak Baki'nin (2019) 8. sınıf Türkçe ders kitabındaki (MEB Yayınları) metinleri incelediği araştırmada gerek öyküleyici gerek bilgilendirici metinlerin daha çok "kolay" düzeydeki metinlerden seçildiği belirlenmiştir. Şakiroğlu (2020) tarafından yalnızca ortaokul Türkçe ders kitaplarındaki öyküleyici metinlerin okunabilirliğini tespit etmeyi amaçlayan araştırmada da metinlerin çoğunluğunun "kolay" düzeye sahip olduğu sonucu elde edilmiştir. İlköğretim Türkçe ders kitaplarındaki öyküleyici türlerden biri olan masalların okunabilirlik düzeylerini inceleyen Zorbaz (2007) da bu türdeki metinlerin "kolay" düzeye sahip olduğunu belirlemiştir. Demir ve Çeçen'e (2013) göre bilgilendirici metinlerde zaman zaman detaylı açıklamalara yer verilmesi ve bunun yanında bu türdeki metinlerin çok sayıda yeni bilgiyi içermesi; öyküleyici metinlerde ise sözlü dilin etkilerinden kaynaklı yargı sayısının azlığı, cümlelerin kısa, dilin sade olması, öyküleyici metinlerin öğrencilerin okuma yaşına daha müsait olması ve bu tür metinlerin öğrenciyi olayın içinde yaşatması, bir duyguyu veya fikri anlatmak amacında olması gibi özellikler, metin türleri arasındaki bu farklılığın sebepleri olarak gösterilmektedir.

Çetinkaya-Uzun formülündeki okunabilirlik düzeyleri dikkate alındığında öyküleyici metinlerin \%83'ünün "eğitsel”, \%10'unun "engelli", \%6'sının "bağımsız"; bilgilendirici metinlerin \%66'sının "eğitsel”, \%31'inin "engelli”, \%3'ünün de "bağımsız" düzeyde olduğu tespit edilmiştir. Buna göre hem öyküleyici hem de bilgilendirici metinlerin büyük bir kısmının "eğitsel" düzeye sahip olduğu, buna karşın "engelli" düzey metinlere bilgilendirici tür kategorisinde daha çok yer ayrıldığı görülmektedir. Bu sonuçlar, Özçetin ve Karakuş’un (2020) 5. sınıf, Okur ve Arı (2013) ile LüleMert'in (2018) 6, 7 ve 8. sinıf, Bora'nın (2019) 5, 6, 7 ve 8. sınıf, Bağc1 ve Ünal (2013) ile Baki'nin (2019) 8. sınıf Türkçe ders kitaplarındaki öyküleyici ve bilgilendirici metinlerin düzeylerini ilgili formüle göre inceledikleri araştırmaların sonuçlarıyla paralellik göstermektedir. Ayrıca 5. sınıf Türkçe ders kitaplarındaki öyküleyici metinlerin okunabilirlik düzeylerini aynı formülle inceleyen Bozlak (2018) da kitaplarda daha çok "eğitsel" düzeyde metinlere yer verildiğini belirtmiştir.

Sonuç olarak ortaokul Türkçe ders kitaplarındaki metinlerin okunabilirlikleriyle bu öğrenim kademesini bitirdikten sonra öğrencilerin karşılarına çıkacak ortaöğretim Türk Dili ve Edebiyatı ders kitaplarındaki metinlerin okunabilirlik düzeylerinin birbirine yakın/benzer olduğu söylenebilir.

Araştırma sonuçları doğrultusunda aşağıdaki önerilere yer verilmiştir:

Kitaplarda her bir okunabilirlik düzeyi örneğini karşılayan metinlerin yer almasına çalışılmalıdır. 
Kitaplar, sınıf seviyesi arttıkça öğrencilerin daha zor metinlerle karşılaşmasını sağlayacak şekilde düzenlenmelidir.

Metinlerdeki ortalama kelime ve cümle uzunluklarının sınıf seviyesine paralel olarak artmasına özen gösterilmelidir.

\section{Araştırmacıların Katkı Oranı}

Araştırma tek yazarlı olduğundan yazarın katkı oranı \%100'dür.

\section{Çıkar Çatışması}

Çalışmada çıkar çatışması oluşturabilecek herhangi bir durum söz konusu değildir.

\section{Kaynaklar}

Akbayır, S. (2006). Cümle ve metin bilgisi. Ankara: Pegem Yayınlar1.

Akkurt, E. (2011). Illköğretim okullarında görev yapan Türkçe öğretmenlerinin 8. sinıf Türkçe ders kitaplarındaki bilgilendirici ve tahkiyeli metinlerin anlaşılabilirlikleri ile ilgili görüşleri ve metinlerin metin okunabilirliği açısından incelenmesi. Yüksek Lisans Tezi, Kırıkkale Üniversitesi, Sosyal Bilimler Enstitüsü, Kırıkkale.

Ateşman, E. (1997). Türkçede okunabilirliğin ölçülmesi. Dil Dergisi, 58, 71-74.

Bağc1, H. (2020). Yabancılara Türkçe öğretiminde kullanılan ileri düzey (C1-C2) ders kitaplarındaki metinlerin okunabilirlik düzeylerinin karşılaştırılması. International Journal of Languages' Education and Teaching, 8(4), 279-295. https://doi.org/10.29228/ijlet.47689

Bağc1, H. ve Ünal, Y. (2013). İlköğretim 8. sınıf Türkçe ders kitaplarındaki metinlerin okunabilirlik düzeyi. Ana Dili Ĕ̈itimi Dergisi, 1(3), 12-28.

Baki, Y. (2019). Türkçe dersi 8. sınıf kitabındaki metinlerin okunabilirliği. Dil Eğitimi ve Araştırmaları Dergisi, 5(1), 30-46. https://doi.org/10.31464/jlere.528298

Baş, B. ve İnan-Yıldız, F. (2015). 2. sınıf Türkçe ders kitabındaki metinlerin okunabilirlik açısından incelenmesi. Mersin Üniversitesi Ĕ̈itim Fakültesi Dergisi, 11(1), 52-61.

Bezirci, B. ve Yılmaz, A. E. (2010). Metinlerin okunabilirliğinin ölçülmesi üzerine bir yazılım kütüphanesi ve Türkçe için yeni bir okunabilirlik ölçütü. DEÜ Mühendislik Fakültesi Fen Bilimleri Dergisi, 12(3), 49-62.

Biçer, N. ve Alan, Y. (2017). Yabancılara Türkçe öğretiminde kullanılan Yeni Hitit 3 ve İstanbul C1+ ders kitaplarındaki metinlerin okunabilirlik düzeylerinin karşılaştırılması. Mersin Üniversitesi Eğitim Fakültesi Dergisi, 13(3), 1130-1139. http://dx.doi.org/10.17860/mersinefd.328486

Bora, A. (2019). Türkçe ders kitaplarındaki metinlerin okunabilirlik yönünden incelenmesi. Yüksek Lisans Tezi, Erzincan Binali Yıldırım Üniversitesi, Sosyal Bilimler Enstitüsü, Erzincan.

Bozlak, Ü. G. (2018). 2016-2017 ve 2017-2018 eğitim ve öğretim yıllarında 5. sınıf Türkçe ders kitaplarındaki hikâye edici metinlerin uzun-çetinkaya formülü ile okunabilirlik düzeyleri/düzeylerinin incelenmesi. Akra Kültür Sanat ve Edebiyat Dergisi, 6(14), 209-234. 
Çeçen, M. A. ve Aydemir F. (2011). Okul öncesi hikâye kitaplarının okunabilirlik açısından incelenmesi. Mustafa Kemal Üniversitesi Sosyal Bilimler Enstitüsü Dergisi, 8(16), 185-194.

Çetinkaya, G. (2010). Türkçe metinlerin okunabilirlik düzeylerinin tanımlanması ve sınıflandırılması. Doktora Tezi, Ankara Üniversitesi, Sosyal Bilimler Enstitüsü, Ankara.

Çiftçi, Ö., Çeçen, M. A. ve Melanlığlu, D. (2007). Altıncı sınıf Türkçe ders kitaplarındaki metinlerin okunabilirlik açısından değerlendirilmesi. Elektronik Sosyal Bilimler Dergisi, 6(22), 206-219.

Çinpolat, E. (2019). Miyase Sertbarut'un kitaplarının okunabilirlik düzeyleri. Yüksek Lisans Tezi, Ordu Üniversitesi, Sosyal Bilimler Enstitüsü, Ordu.

Demir, M. ve Çeçen, M. A. (2013). İlköğretim I-V. sınıflar Türkçe ders kitaplarındaki metinlerin okunabilirlik açısından değerlendirilmesi. Milli Ĕ̈itim Dergisi, 197, 80-94.

Duran, E. ve Erkek, G. (2018). Ortaokul 8. sınıf öğrencilerinin okuma ön yargılarının belirlenmesi. Ahi Evran Üniversitesi Sosyal Bilimler Enstitüsü Dergisi, 4(1), 1-17. DOI: 10.31592/aeusbed.368064

Erdem, C. (2011). Dil ve Anlatım ders kitaplarındaki metinlerin kelime-cümle uzunluklarl ve okunabilirlik düzeyleri üzerine bir değerlendirme. Yüksek Lisans Tezi, Gazi Üniversitesi, Eğitim Bilimleri Enstitüsü, Ankara.

Güneş, F. (2014). Türkçe öğretimi-yaklaşımlar ve modeller. Ankara: Pegem Yayınları.

İskender, E. (2013). Türkçe ders kitaplarındaki metinlerin kelime ve cümle yapılarıyla okunabilirlik düzeyleri arasındaki ilişki. Yüksek Lisans Tezi, Karadeniz Teknik Üniversitesi, Eğitim Bilimleri Enstitüsü, Trabzon.

Kapıkıran, Ş. ve Susar Kırmızı, F. (2019). Öğretmen adaylarının merak ve keşfetme algıları ile okuma alışkanlığına yönelik tutumları arasındaki ilişki. Ahi Evran Üniversitesi Sosyal Bilimler Enstitüsü Dergisi, 5(2), 251-265. DOI: 10.31592/aeusbed.585328

Karasar, N. (2005). Bilimsel araştırma yöntemi. Ankara: Nobel Yayınları.

Karatay, H., Bolat, K. K. ve Güngör, H. (2013). Türkçe ders kitaplarındaki metinlerin okunabilirlik ve anlaş1labilirliği. The Journal Academic Social Science Studies, 6(6), 603-623. http://dx.doi.org/10.9761/JASSS1770

Kayabaşı, B., Yılmaz, M. ve Doyumağaç, İ. (2016). Mustafa Ruhi Şirin hikâyelerinin okunabilirlik açısından incelenmesi. Adıyaman Üniversitesi Ĕ̆itim Bilimleri Dergisi, 6(2), 323-343.

Lüle-Mert, E. (2018). Türkçe ders kitaplarındaki metinlerin okunabilirlikleri. International Journal of Language Academy, 6(1), 184-198. http://dx.doi.org/10.18033/ijla.3866

Mutlu, H. H. (2020). Yabancılara Türkçe öğretiminde kullanılan ders kitaplarında (İstanbul Yabancılar İçin Türkçe Öğretim Seti, Yedi İklim Öğretim Seti) yer alan metinlerin okunabilirlik düzeylerinin incelenmesi. Avrasya Uluslararası Araştırmalar Dergisi, 8(22), 371-386.

Okur, A. ve Arı, G. (2013). 6, 7, 8. sınıf Türkçe ders kitaplarındaki metinlerin okunabilirliği. İlköğretim Online, 12(1), 202-226.

Özbek, A. B. ve Ergül, C. (2018). İlkokul 4. sınıf ders kitaplarının okunabilirliklerinin değerlendirilmesi. Mersin Üniversitesi Eğitim Fakültesi Dergisi, 14(2), 653-668. https://doi.org/10.17860/mersinefd.398401 
Özcan, K. (2020). TÜBİTAK'ın yayımladı̆̆ı sorun odaklı çocuk kitaplarının biçim-içerik ve okunabilirlik açısından incelenmesi. Yüksek Lisans Tezi, Tokat Gaziosmanpaşa Üniversitesi, Eğitim Bilimleri Enstitüsü, Tokat.

Özçetin, K. ve Karakuş, N. (2020). 5. sınıf Türkçe ders kitaplarındaki metinlerin okunabilirlik yönünden incelenmesi. Türkiye Ĕgitim Dergisi, 5(1), 175-190.

Özdemir, S. (2016). Beşinci sınıf Türkçe ders kitabındaki öyküleyici ve bilgilendirici metinlerin okunabilirlik durumu. Stnırsız Eğitim ve Araştırma Dergisi, 1(1), 33-46.

Özgü-Koçağan, F. (2012). İlköğretim 4-5. sınıf için hazırlanan öyküleyici çocuk kitaplarının okunabilirlik ve değerler yönünden incelenmesi. Yüksek Lisans Tezi, Abant İzzet Baysal Üniversitesi, Eğitim Bilimleri Enstitüsü, Bolu.

Pilav, S. ve Ünalan, Ş. (2012). Yazılı ve sözlü anlatım. Ankara: Nobel Yayıncılık.

Şakiroğlu, Y. (2020). Ortaokul Türkçe ders kitaplarındaki öykülerin kelime-cümle uzunlukları ve okunabilirlik düzeyleri üzerine bir inceleme. Anemon Muş Alparslan Üniversitesi Sosyal Bilimler Dergisi, 8(6), 1827-1834.

Teke, S. (2016). Çocuk edebiyatı yazarı Hasan Kallimci'nin öykülerinin okunabilirlik açısından değerlendirilmesi. Yüksek Lisans Tezi, Sakarya Üniversitesi, Eğitim Bilimleri Enstitüsü, Sakarya.

Temizyürek, F. (2010). Türkiye'de okuma seferberliği çerçevesinde seçilen kitapların kelime-cümle uzunlukları ve okunabilirlik açısından incelenmesi. Türklük Bilimi Araştırmaları Dergisi, 27, 645-654.

Temur, T. (2003). Okunabilirlik (readability) kavramı. Türklük Bilimi Araştırmaları Dergisi, 13, 169180.

Tosunoğlu, M. ve Özlük, Y. Ö. (2011). Okunabilirlik ve ilköğretim 1. sınıf Türkçe ders kitabındaki düz yazı metinlerinin okunabilirlik açısından değerlendirilmesi. Millî Ĕ̌itim Dergisi, 189, 219-230.

Yıldırım, A. ve Şimşek, H. (2011). Sosyal bilimlerde nitel araştırma yöntemleri. Ankara: Seçkin Yayıncilik.

Yılmaz, F. ve Temiz, Ç. (2014). Yabancılara Türkçe öğretiminde kullanılan ders kitaplarındaki metinlerin okunabilirlik durumları. International Journal of Languages' Education and Teaching, 2, 81-91.

Ziya, S. (2019). Behiç Ak'ın çocuk romanlarının söz varlı̆̆ ve okunabilirlik yönünden değerlendirilmesi. Yüksek Lisans Tezi, Erciyes Üniversitesi, Eğitim Bilimleri Enstitüsü, Kayseri.

Zorbaz, K. Z. (2007). Türkçe ders kitaplarındaki masalların kelime-cümle uzunlukları ve okunabilirlik düzeyleri üzerine bir değerlendirme. Ĕgitimde Kuram ve Uygulama, 3(1), 87-101.

Zorbaz, K. Z. ve Köroğlu M. (2016). Gazi TÖMER Yabancılar İçin Türkçe Öğretim Setindeki metinlerin kelime-cümle uzunlukları ve okunabilirlik düzeyleri. Turkish Studies, 11(3), 25092524. http://dx.doi.org/10.7827/TurkishStudies.9290 


\section{Extended Abstract}

\section{Introduction}

The aim of this study is to determine the readability levels of the texts in the high school Turkish Language and Literature textbooks. The main purpose of readability, defined as "How easy or difficult the texts are to be understood by the reader" (Ateşman, 1997), is to determine the difficulty of the text based on the word/sentence length of the texts and to determine the suitability of the texts to the reader's level based on this ratio (Baki, 2019). Readability is a concept related to the formal features of the texts. Increasing the number of syllables in a word and the number of words in a sentence decreases the readability level of the text (Özbek and Ergül, 2018). For this reason, readability is extremely important in both mother tongue and foreign language teaching. When the studies on readability are examined, it is seen that there are also studies aimed at determining the readability levels of various literary works, especially determining the readability of texts in Turkish textbooks for primary, secondary and foreigners. However, the lack of research on high school textbooks prepared for the high school Turkish Language and Literature courses conducted in a textbased manner draws attention. In the current study, which was conducted based on the question of "What are the readability levels of the texts in the Turkish Language and Literature textbooks?", 6 subproblems are included.

\section{Method}

This study, which aims to determine the readability levels of texts in Turkish Language and Literature textbooks, was carried out as a document analysis in the qualitative research design. The sample of the research consisted of a total of 76 texts. 16 texts are from the 9th-grade textbook, 19 are from the 10th-grade textbook, 23 are from the 11th textbook, and 18 are from the 12th-grade book. 40 of these texts are narrative, and 36 of them are informative. After the syllable, word and sentence numbers of the texts in the sample were determined, the average word length was calculated by dividing the total number of syllables by the total number of words, and the average sentence length was calculated by dividing the total number of words by the total number of sentences. The data obtained were placed into Ateşman (1997) and Çetinkaya-Uzun's (2010) formulas separately, and the readability scores of the texts were determined.

\section{Findings}

Considering the readability levels according to the grade levels and text types (according to the Ateşman formula), it was determined that "easy" and "medium difficulty" texts were equally distributed in the narrative texts in the 9th-grade textbook, and "medium difficulty" texts were predominant $(50 \%)$ in informative texts. In the narrative texts in the 10th-grade textbook, "medium difficulty" texts were predominant (57\%), and it was determined that in the informative text category, there were more "medium difficulty" texts $(60 \%)$. In the 11th grade textbook, the "easy" level was prominent $(80 \%)$ in narrative texts, while in the informative type, it was determined that "medium difficulty" texts were used more $(62 \%)$. In the narrative texts in the 12th-grade textbook, it was determined that "easy" texts were predominant (70\%), and in informative texts, "medium difficulty" texts were dominant (50\%). As a result of examining the readability levels according to the ÇetinkayaUzun formula, it was found that all of the narrative texts in the 9th-grade textbook and $70 \%$ of the informative texts were at "educational" level. $65 \%$ of the narrative texts and $60 \%$ of the informative texts in the 10th grade; $90 \%$ of narrative texts and $61 \%$ of informative texts in the 11th grade and $90 \%$ of narrative texts and $75 \%$ of informative texts in 12 th grade consisted of "educational" level texts.

When looking at the average word lengths by grade levels and text types, the average word lengths in both informative and narrative texts are shorter in the 9th and 11th grades than in the 10th and 12th grades. The average sentence length of narrative texts decreases as the grade level increases, 
while those of the informative texts gradually increases from the 9th grade to the 11th grade and decreases again at the 12th grade.

Considering the distribution of readability levels by text types, it was determined that $55 \%$ of the narrative texts are "easy", $40 \%$ are "medium" and 5\% are "difficult" level texts according to the Ateşman formula. $56 \%$ of the informative texts are at the "medium", $19 \%$ are "easy", $15 \%$ are "difficult", $8 \%$ are "very difficult" and 3\% are "very easy" level. Considering the readability levels in the Çetinkaya-Uzun formula, $83 \%$ of the narrative texts are "educational", $10 \%$ are "insufficient", $6 \%$ are "independent"; $66 \%$ of the informative texts are found to be "educational", $31 \%$ are "insufficient" and $3 \%$ are "independent".

\section{Conclusion and Discussion}

According to the results of the study, it can be said that the higher the grade level, the easier the narrative texts are selected from among the texts. Informative texts include more "medium difficulty" texts at all grade levels, and it has been observed that the variety of readability levels are richer in these texts. It has been found that informative texts have longer word averages than narrative texts at the average word and sentence lengths in all grades. Considering the average sentence lengths according to grade levels, it has been determined that informative texts except for the texts in the 9thgrade book have longer sentences than the narrative texts. When the distribution of the average readability scores of the texts according to the grade level is examined, the easiest texts are in 11th grade in narrative texts and the 9th grade in informative texts. On the other hand, the most difficult texts in narrative texts are in the 10th grade and informative texts in the 11th grade. Accordingly, it has been revealed that the 11th-grade textbook contains easier texts in narrative type and more difficult texts in informative type. It is seen that these results obtained support the results of the studies (Ar1 ve Okur, 2013; Baki, 2019; Baş ve İnan-Yıldız, 2015; Çiftçi, Çeçen ve Melanlıoğlu, 2007; Demir ve Çeçen, 2013; Özçetin ve Karakuş, 2020; Özdemir, 2016) conducted in the literature on the subject. 